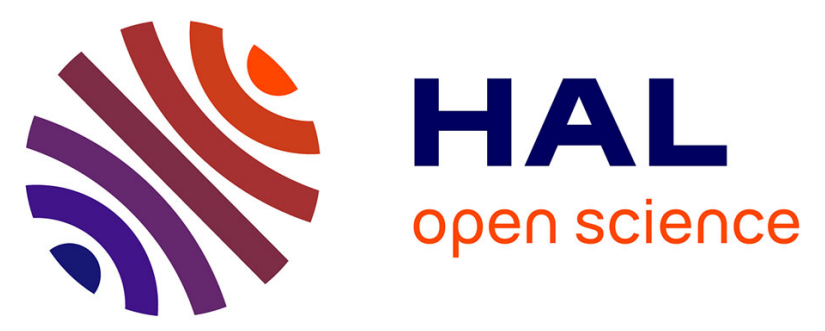

\title{
Reduced N cycling in response to drought, warming, and elevated CO2 in a Danish heathland: Synthesizing results of the CLIMAITE project after two years of treatments
}

Klaus Steenberg Larsen, Louise C. Andresen, Claus Beier, Sven Jonasson, Kristian R. Albert, Per Ambus, Karen Stevnbak, Marie Frost Arndal, Mette S. Carter, Soren Christensen, et al.

\section{- To cite this version:}

Klaus Steenberg Larsen, Louise C. Andresen, Claus Beier, Sven Jonasson, Kristian R. Albert, et al.. Reduced N cycling in response to drought, warming, and elevated CO2 in a Danish heathland: Synthesizing results of the CLIMAITE project after two years of treatments. Global Change Biology, 2010, 17 (5), pp.1884. 10.1111/j.1365-2486.2010.02351.x . hal-00599531

\section{HAL Id: hal-00599531 https://hal.science/hal-00599531}

Submitted on 10 Jun 2011

HAL is a multi-disciplinary open access archive for the deposit and dissemination of scientific research documents, whether they are published or not. The documents may come from teaching and research institutions in France or abroad, or from public or private research centers.
L'archive ouverte pluridisciplinaire HAL, est destinée au dépôt et à la diffusion de documents scientifiques de niveau recherche, publiés ou non, émanant des établissements d'enseignement et de recherche français ou étrangers, des laboratoires publics ou privés. 


\section{Global Change Biology}

\section{Reduced $\mathbf{N}$ cycling in response to drought, warming, and elevated $\mathrm{CO} 2$ in a Danish heathland: Synthesizing results of the CLIMAITE project after two years of treatments}

\begin{tabular}{|c|c|}
\hline Journal: & Global Change Biology \\
\hline Manuscript ID: & GCB-10-0587 \\
\hline Wiley - Manuscript type: & Primary Research Articles \\
\hline $\begin{array}{r}\text { Date Submitted by the } \\
\text { Author: }\end{array}$ & $16-J u l-2010$ \\
\hline Complete List of Authors: & $\begin{array}{l}\text { Larsen, Klaus; Technical University of Denmark, Risø National } \\
\text { Laboratory for Sustainable Energy, Biosystems Division } \\
\text { Andresen, Louise; University of Copenhagen, Institute of Biology } \\
\text { Beier, Claus; Technical University of Denmark; Technical University } \\
\text { of Denmark, Risø National Laboratory for Sustainable Energy, } \\
\text { Biosystems Division } \\
\text { Jonasson, Sven; University of Copenhagen, Institute of Biology } \\
\text { Albert, Kristian; Risø National Laboratory for Sustainable Energy, } \\
\text { Technical University of Denmark, Biosystems Division; Technical } \\
\text { University of Denmark, Risø National Laboratory for Sustainable } \\
\text { Energy, Biosystems Division } \\
\text { Ambus, Per; Risø DTU, Biosystems; Technical University of } \\
\text { Denmark, Risø National Laboratory for Sustainable Energy, } \\
\text { Biosystems Division } \\
\text { Stevnbak, Karen; University of Copenhagen, Biology; University of } \\
\text { Copenhagen, Institute of Biology } \\
\text { Arndal, Marie; University of Copenhagen, Forest and Landscape } \\
\text { Carter, Mette; Ris } \varnothing \text { National Laboratory for Sustainable Energy, } \\
\text { Technical University of Denmark, Biosystems Division; Technical } \\
\text { University of Denmark, Risø National Laboratory for Sustainable } \\
\text { Energy, Biosystems Division } \\
\text { Christensen, Soren; University of Copenhagen, Institute of Biology } \\
\text { Holmstrup, Martin; National Environmental Research Institute, } \\
\text { Terrestrial Ecology } \\
\text { Ibrom, Andreas; Technical University of Denmark, Risø National } \\
\text { Laboratory for Sustainable Energy, Biosystems Department; } \\
\text { Technical University of Denmark, Risø National Laboratory for } \\
\text { Sustainable Energy, Biosystems Division; Risø Nationa Laboratory } \\
\text { for Sustainable Energy, Biosystems Division } \\
\text { Kongstad, Jane; University of Copenhagen, Forest and Landscape } \\
\text { Ecology; University of Copenhagen, Forest and Landscape } \\
\text { van der Linden, Leon; RIS } \varnothing-D T U \text { National Laboratory for } \\
\text { Sustainable Energy, Biosystems Division; Technical University of }\end{array}$ \\
\hline
\end{tabular}


Abstract:

Keywords:

Denmark, Risø National Laboratory for Sustainable Energy, Biosystems Division

Maraldo, Kristine; National Environmental Research Institute, Department of Terrestrial Ecology; National Environmental Research Institute, Terrestrial Ecology

Michelsen, Anders; Biology, Terrestrial Ecology; University of Copenhagen, Institute of Biology

Mikkelsen, Teis; Technical University of Denmark, Risø National Laboratory for Sustainable Energy, Biosystems Division Pilegaard, Kim; Technical University of Denmark, Risø National Laboratory for Sustainable Energy, Biosystems Division; Risø National Laboratory for Sustainable Energy, Technical University of Denmark, Biosystems Division

Prieme, Ambers; Copenhagen University, Dep. of Biology; University of Copenhagen, Institute of Biology Ro-Poulsen, Helge; University of Copenhagen, Institute of Biology Schmidt, Inger K.; University of Copenhagen, Forest \& Landscape; University of Copenhagen, Forest and Landscape

Selsted, Merete; Risø National Laboratory for Sustainabel Energy, DTU, Biosystems; Technical University of Denmark, Risø National Laboratory for Sustainable Energy, Biosystems Division

Climate driver interactions, $\mathrm{C} / \mathrm{N}$ ratio, multi-factor climate change experiment, nitrogen cycling, nitrogen mineralization, N2O, soil fauna

Field-scale experiments simulating realistic future climate scenarios are important tools for investigating the effects of current and future climate changes on ecosystem functioning and biogeochemical cycling. We exposed a semi-natural Danish heathland ecosystem to elevated atmospheric carbon dioxide (CO2), warming, and extended summer drought in all combinations. Here, we report on the short-term responses of the nitrogen $(\mathrm{N})$ cycle after two years of treatments.

Elevated $\mathrm{CO} 2$ significantly affected above-ground stoichiometry by increasing the carbon to nitrogen $(\mathrm{C} / \mathrm{N})$ ratios in the leaves of both co-dominant species (Calluna vulgaris and Deschampsia flexuosa), as well as the $\mathrm{C} / \mathrm{N}$ ratios of Calluna flowers and by reducing the $\mathrm{N}$ concentration of Deschampsia litter. Below-ground, elevated $\mathrm{CO} 2$ had only minor effects, whereas warming increased $\mathrm{N}$ turnover, as indicated by increased rates of microbial $\mathrm{NH} 4+-\mathrm{N}$ consumption, gross mineralization, potential nitrification, denitrification and N2O emissions. Drought reduced below-ground gross $\mathrm{N}$ mineralization and decreased fauna $\mathrm{N}$ mass and $\mathrm{N}$ mineralization. Leaching was unaffected by treatments but was significantly higher across all treatments in the second year than in the much drier first year indicating that ecosystem $\mathrm{N}$ loss is highly sensitive to changes and variability in amount and timing of precipitation. Interactions between treatments were common and although some synergistic effects were observed, antagonism dominated the interactive responses in treatment combinations, i.e. responses were smaller in combinations than in single treatments. Nonetheless, increased $\mathrm{C} / \mathrm{N}$ ratios of photosynthetic tissue, decreased litter $\mathrm{N}$ production, and decreased fauna $\mathrm{N}$ mineralization prevailed in the full treatment combination indicating reduced $\mathrm{N}$ turnover in the simulated future climate scenario, which could act to reduce the potential growth response of plants to elevated atmospheric $\mathrm{CO} 2$ concentration. In conclusion, effects observed in single-factor studies should be evaluated with caution. Multi-factor climate experiments are needed for improving realistic estimation of the combined ecosystem responses to future climate changes. 


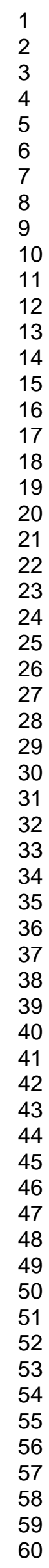


1 Title: Reduced $\mathrm{N}$ cycling in response to drought, warming, and elevated $\mathrm{CO}_{2}$ in a Danish

2 heathland: Synthesizing results of the CLIMAITE project after two years of treatments

3

$4 \quad$ Running title: Effects of climate change on N cycling

5

6

7

8

9

Authors: Klaus S. Larsen ${ }^{1}$, Louise C. Andresen ${ }^{2}$, Claus Beier ${ }^{1}$, Sven Jonasson ${ }^{2}$, Kristian R. Albert $^{1}$, Per Ambus ${ }^{1}$, Karen S. Andersen ${ }^{2}$, Marie F. Arndal ${ }^{3}$, Mette S. Carter ${ }^{1}$, Søren

Christensen $^{2}$, Martin Holmstrup ${ }^{4}$, Andreas Ibrom ${ }^{1}$, Jane Kongstad $^{3}$, Leon van der Linden ${ }^{1}$, Kristine Maraldo ${ }^{4}$, Anders Michelsen $^{2}$, Teis N. Mikkelsen ${ }^{1}$, Kim Pilegaard $^{1}$, Anders Priemé$^{2}$, Helge Ro-Poulsen ${ }^{2}$, Inger K. Schmidt ${ }^{3}$, Merete B. Selsted ${ }^{1}$

${ }^{1}$ Technical University of Denmark, Ris $\phi$ DTU, Biosystems Division, Frederiksborgvej 399, DK-4000 Roskilde, Denmark.

${ }^{2}$ University of Copenhagen, Institute of Biology, Øster Farimagsgade 2D, DK-1353

Copenhagen K, Denmark.

${ }^{3}$ University of Copenhagen, Forest and Landscape, Horsholm Kongevej 11, DK-2970

Horsholm, Denmark.

${ }^{4}$ National Environmental Research Institute, Department of Terrestrial Ecology, Aarhus University, Vejlsфvej 25, DK-8600 Silkeborg, Denmark.

Corresponding author: Klaus S. Larsen, klas@ risoe.dtu.dk, phone: +45 46774157

Keywords: Climate driver interactions, $\mathrm{C} / \mathrm{N}$ ratio, multi-factor climate change experiment, nitrogen cycling, nitrogen mineralization, $\mathrm{N}_{2} \mathrm{O}$, soil fauna 


\section{Abstract}

Field-scale experiments simulating realistic future climate scenarios are important tools for investigating the effects of current and future climate changes on ecosystem functioning and biogeochemical cycling. We exposed a semi-natural Danish heathland ecosystem to elevated atmospheric carbon dioxide $\left(\mathrm{CO}_{2}\right)$, warming, and extended summer drought in all combinations. Here, we report on the short-term responses of the nitrogen $(\mathrm{N})$ cycle after two years of treatments.

Elevated $\mathrm{CO}_{2}$ significantly affected above-ground stoichiometry by increasing the carbon to nitrogen $(\mathrm{C} / \mathrm{N})$ ratios in the leaves of both co-dominant species (Calluna vulgaris and Deschampsia flexuosa), as well as the $\mathrm{C} / \mathrm{N}$ ratios of Calluna flowers and by reducing the $\mathrm{N}$ concentration of Deschampsia litter. Below-ground, elevated $\mathrm{CO}_{2}$ had only minor effects, whereas warming increased $\mathrm{N}$ turnover, as indicated by increased rates of microbial $\mathrm{NH}_{4}{ }^{+}-\mathrm{N}$ consumption, gross mineralization, potential nitrification, denitrification and $\mathrm{N}_{2} \mathrm{O}$ emissions. Drought reduced below-ground gross $\mathrm{N}$ mineralization and decreased fauna $\mathrm{N}$ mass and $\mathrm{N}$ mineralization. Leaching was unaffected by treatments but was significantly higher across all treatments in the second year than in the much drier first year indicating that ecosystem $\mathrm{N}$ loss is highly sensitive to changes and variability in amount and timing of precipitation.

Interactions between treatments were common and although some synergistic effects were observed, antagonism dominated the interactive responses in treatment combinations, i.e. responses were smaller in combinations than in single treatments. Nonetheless, increased $\mathrm{C} / \mathrm{N}$ ratios of photosynthetic tissue, decreased litter $\mathrm{N}$ production, and decreased fauna $\mathrm{N}$ mineralization prevailed in the full treatment combination indicating reduced $\mathrm{N}$ turnover in 
48 the simulated future climate scenario, which could act to reduce the potential growth response 49 of plants to elevated atmospheric $\mathrm{CO}_{2}$ concentration.

50 In conclusion, effects observed in single-factor studies should be evaluated with

51 caution. Multi-factor climate experiments are needed for improving realistic estimation of the 52 combined ecosystem responses to future climate changes. 


\section{Introduction}

Climate change with elevated atmospheric $\mathrm{CO}_{2}$, increased temperature and altered precipitation will fundamentally affect key drivers for ecosystem functioning and lead to adverse effects in terrestrial ecosystems across the globe (IPCC, 2007). These climate-driven changes may affect ecosystem functioning directly, e.g. through $\mathrm{CO}_{2}$-stimulated photosynthesis and growth (Luo et al. 2006; de Graaff et al. 2006), warming-induced increased nutrient mineralization (Emmett et al. 2004) or drought-induced growth limitation (Penuelas et al. 2007). They may also act indirectly e.g. through impacts on species composition (Penuelas et al. 2007).

Growth in many natural and semi-natural terrestrial ecosystems is limited by nitrogen and characterized by strong competition for nitrogen between plants and the soil communities of fungi and bacteria (Marion et al. 1989; Jonasson et al. 1996). Consequently, ecosystem N availability is an important factor controlling the carbon uptake in terrestrial ecosystems and therefore also plays a dominant role in controlling the feedback between the biosphere and the atmosphere in a warmer and more $\mathrm{CO}_{2}$ enriched world. The theory of nitrogen as a limiting factor constraining the carbon uptake in terrestrial ecosystems in response to elevated $\mathrm{CO}_{2}$ is conceptualized in the PNL framework (Progressive Nitrogen Limitation) (Luo et al. 2004) describing how increased carbon sequestration driven by elevated $\mathrm{CO}_{2}$ requires increased access to nitrogen in order to balance the carbon input. Accordingly, without additional inputs of plant-available $\mathrm{N}$, nitrogen will progressively limit further carbon uptake. But increased $\mathrm{N}$ availability has also been shown as a consequence of increased availability of labile soil carbon substrate (Zak et al. 1993) and increased soil moisture content due to improved plant water use efficiency (WUE) (Zak et al. 1993; Hungate 1999), as well as increased N mineralization in response to warming (Schmidt et al. 2004; Emmett et al. 2004). The 
interaction between the carbon and nitrogen cycles clearly illustrates how sensitive

ecosystems are to changes in nitrogen pools and turnover, current input of $\mathrm{N}$, and other nutrients, and changes in the water regime. This is particularly important for $\mathrm{N}$ limited systems, such as natural and semi-natural ecosystems with relatively low nitrogen inputs and internal $\mathrm{N}$ turnover rates of the mineral $\mathrm{N}$ pool as fast as a few days (Davidson et al. 1990; Lipson \& Näsholm 2001; Schimel \& Bennett 2004; Vervaet et al. 2004). In systems with very high internal turnover rates of nitrogen, the $\mathrm{N}$ turnover has also been shown to be very sensitive to changes in natural climatic variations such as reduced water availability (Jamieson et al. 1999), potentially leading to a high sensitivity of these systems to climatedriven changes in the internal processes regulating the demand or supply of nitrogen.

Most of the experimental evidence of PNL and the role of nitrogen in constraining carbon uptake is based on modeling studies (Rastetter et al. 1997) or on experiments involving elevated $\mathrm{CO}_{2}$ alone or in combination with various levels of nitrogen addition to demonstrate the role of $\mathrm{N}$ in stimulating $\mathrm{CO}_{2}$ sequestration responses (Lutze \& Gifford 2000; Lutze et al. 2000; van Heerwaarden et al. 2005; de Graaff et al. 2006; Reich et al. 2006). However, in a future $\mathrm{CO}_{2}$ enriched world, the nitrogen limitation and the $\mathrm{CO}_{2}$ response in $\mathrm{N}$ limited systems will to a large extent be regulated by the climate change-associated responses of the internal nitrogen cycle, which are not well captured in $\mathrm{CO}_{2}$ alone experiment. For instance, it has been demonstrated that warming can stimulate internal nitrogen mineralization, leading to increased $\mathrm{N}$ availability (Emmett et al. 2004) and even increased $\mathrm{N}$ leaching (Lukewille \& Wright 1997; Schmidt et al. 2004). Correspondingly, changes in water availability, such as water limitations by droughts, can reduce $\mathrm{N}$ mineralization and $\mathrm{N}$ availability (Emmett et al. 2004). On the other hand, increased water availability due to increased precipitation or to $\mathrm{CO}_{2}$ stimulated increase in WUE can increase $\mathrm{N}$ mineralization and $\mathrm{N}$ availability under water limited conditions (Hungate 1999). Since the future climate 
103 change will involve changes in all of these factors, it is important to understand the possible 104 interactions between different climate drivers on $\mathrm{N}$ availability and nitrogen limitation.

105 Therefore, studies involving all factors simultaneously are needed.

106 In the present study, we aim to synthesize the overall impacts of changes in the nitrogen 107 cycle in response to warming, elevated atmospheric $\mathrm{CO}_{2}$ concentration and increased summer 108 drought events after two years of treatments. We compare the responses of the three-factor 109 treatment with responses to treatments including only one, or pair wise combinations of the 110 factors.

111 In response to elevated $\mathrm{CO}_{2}$, we expected to observe increased plant tissue and litter 112 C/N ratios (Paterson et al. 1999; Lutze \& Gifford 2000; van Heerwaarden et al. 2005; Finzi et 113 al. 2006; Chen et al. 2007; Hovenden et al. 2008). In the short term, we further expected that 114 the increased water use efficiency under elevated $\mathrm{CO}_{2}$ (Ainsworth \& Long 2005; Leuzinger \& 115 Körner 2007; Ainsworth \& Rogers 2007; Albert et al. 2010) would stimulate plant growth, 116 and increase plant $\mathrm{N}$ demand and biomass, and that concomitant increased rhizodeposition 117 would lead to increased microbial biomass activity and mineralization. Warming was 118 expected to increase plant growth and increase mineralization (Rustad et al. 2001), whereas 119 extended summer drought was expected to reduce plant $\mathrm{N}$ demand and decrease $\mathrm{N}$ 120 mineralization and nitrification rates (Emmett et al. 2004; Schmidt et al. 2004; Sowerby et al. 121 2008) as a product of direct or indirect effects on microbial activity. Assuming simple 122 addition of these single treatment effects, we expected that drought effects would be reduced 123 in combination with both warming and elevated $\mathrm{CO}_{2}$ and, consequently, that increased $\mathrm{N}$ 124 mineralization and plant growth in response to both warming and elevated $\mathrm{CO}_{2}$ would 125 dominate over decreases caused by drought in the full combination of treatments. 


\section{Materials and methods}

\section{Experimental site and climate change manipulations}

The CLIMAITE experimental site is a dry, temperate heathland situated approximately $50 \mathrm{~km}$ NW of Copenhagen, Denmark $\left(55^{\circ} 53^{\prime} \mathrm{N}, 11^{\circ} 58^{\prime} \mathrm{E}\right)$. The vegetation is dominated by the evergreen dwarf shrub Calluna vulgaris (L.), the perennial grass Deschampsia flexuosa (L.) and various mosses and herbs. The soil is a well-drained, nutrient-poor sandy deposit with a $\mathrm{pH}$ of 4-5 and an organic top layer ranging from 2 to $5 \mathrm{~cm}$ in depth. Long-term annual mean air temperature is $8.0{ }^{\circ} \mathrm{C}$, annual mean precipitation is $613 \mathrm{~mm}$ (Danish Meteorological Institute 2009) and the total $\mathrm{N}$ bulk deposition at the site was $1.27 \pm 0.07$ and $1.35 \pm 0.04 \mathrm{~g} \mathrm{~N} \mathrm{~m}^{-}$ ${ }^{2} y^{-1}$ in 2006 and 2007, respectively (Larsen KS, unpublished data). The experimental area covers approximately 2 ha and consists of twelve $7 \mathrm{~m}$ diameter octagons laid out pair-wise in 6 blocks ( $=6$ replicates). Each block consists of two octagons, one with ambient (A) atmospheric $\mathrm{CO}_{2}$ and one receiving elevated atmospheric $\mathrm{CO}_{2}$ concentration $\left(\mathrm{CO}_{2}\right)(510 \mathrm{ppm}$ in a free air $\mathrm{CO}_{2}$ enrichment setup (FACE)). Each octagon is separated into 4 subplots receiving in addition to the ambient or elevated $\mathrm{CO}_{2} 1$ ) one month summer drought (D) by rain-out shelters, 2) passive warming (T) of air and soil by night time warming curtains $50 \mathrm{~cm}$ above ground, 3) a combination of drought and warming (TD) or 4) no drought or temperature treatment. In total, the experiment provides a full factorial design with all 7 combinations of $\mathrm{D}, \mathrm{T}$ and $\mathrm{CO}_{2}$ and an untreated control for reference (A). Details on the experimental setup are described by Mikkelsen et al. (2008).

The treatments were initiated in October 2005 and the first summer drought was applied in July/August 2006. The warming treatment elevated temperature at $5 \mathrm{~cm}$ depth by $0.3{ }^{\circ} \mathrm{C}$ in the winter to $0.7^{\circ} \mathrm{C}$ in the summer months, on average. The maximum mean daily temperature elevation was $1.2,2.1$ and $2.8^{\circ} \mathrm{C}$ in the $5 \mathrm{~cm}$ depth, soil surface and $20 \mathrm{~cm}$ height 
151 sensors, respectively (4 October 2005 - 31 December 2007). The drought campaigns removed

$15252 \mathrm{~mm}$ and $94 \mathrm{~mm}$ of precipitation, resulting in peak reductions of soil water content of 11

153 and $13 \%$ v/v over 0-20 cm soil depth in 2006 (3-20 July and 26 July-4 August) and 2007 (21

154 May-22 June), respectively. The drought campaigns were stopped when soil water content

155 reached about $5 \%$ v/v over $0-20 \mathrm{~cm}$ soil depth.

156

$157 N$ stocks in plants, litter, microbes and soil, C/N ratios, extractable $N$ concentrations

158 Above-ground biomasses $\mathrm{N}$ of Calluna and Deschampsia were estimated from non-

159 destructive point intercept measurements in two $50 \times 50 \mathrm{~cm}$ subplots within each plot

160 combined with a linear regression model linking point intercept measurements and biomass

161 obtained from destructive harvesting of similar plots outside the treatment plots (Jonasson

162 1988; Kongstad et al. 2010; Riis-Nielsen \& Schmidt 2010). To compensate for pre-treatment

163 differences between the initial biomass values in individual sub-plots and the subsequent

164 development during the experiment, treatment effects on above-ground plant biomasses were

165 normalized and scaled to the average biomass development in the ambient plots while

166 maintaining the observed relative variance. Briefly, a regression was fitted between the pre-

167 treatment plant biomass and the treatment biomass at a given time point, within each

168 treatment. The slope of the regression in the ambient treatment defined the ambient or control

169 response; the normalized treatment effect was determined as the difference between the

170 predicted control response and the predicted treatment response for a given treatment. See van

171 der Linden et al. (2010) for further description.

$172 \quad$ Calluna and Deschampsia plants as well as mosses from the experimental plots were

173 harvested in August 2007. The C and N concentrations measured in green tissue, flowers,

$174 \mathrm{wood} / \mathrm{stem}$ and roots or whole plants (mosses) (Andresen et al. 2010a) were used to calculate 
$175 \mathrm{C} / \mathrm{N}$ ratios. The $\mathrm{N}$ concentrations were used in combination with the non-destructive above176 ground biomass estimates to calculate the total $\mathrm{N}$ stock of these pools. Concurrent with plant 177 harvest, soil samples from each plot $(0-10 \mathrm{~cm}$ soil depth) were taken to measure plant root 178 biomasses, microbial biomass $\mathrm{N}$ and, soil organic matter $\mathrm{N}$ (SOM-N) and soil extractable $179 \mathrm{NO}_{3}-\mathrm{N}, \mathrm{NH}_{4}-\mathrm{N}$ and dissolved organic nitrogen (DON) (Andresen et al. 2010a). Litter 180 production by Deschampsia was estimated from point intercept-based difference between 181 seasonal minimum and maximum biomass of live and dead fractions of Deschampsia leaves 182 multiplied with N concentrations in the litter (Kongstad et al. 2010; Riis-Nielsen \& Schmidt 183 2010).

\section{Soil fauna}

Soil cores within each plot $(0-10 \mathrm{~cm}$ soil depth) were sampled in October and November 2007

187 for biomass estimation of protozoa/nematodes and enchytraeids/microarthropodes,

188 respectively. For estimation of protozoan biomass, a soil suspension was prepared by

189 blending $5 \mathrm{~g}$ of soil with $100 \mathrm{ml}$ of Amoeba Saline (AS, Page 1988) for $1 \mathrm{~min}$. Three-fold

190 dilution series of the soil suspension were prepared in microtiter plates being inspected for

191 protozoa after one and three weeks of growth at $15^{\circ} \mathrm{C}$ with a modified version of the Most

192 Probable Number method (Darbyshire et al. 1974; Rønn et al. 1995). Nematodes were

193 extracted from between 10 and $11 \mathrm{~g}$ (fresh weight) of soil by a modified Baermann tray

194 extraction method (Georgieva et al. 2005). Samples were extracted for 48 h, and nematodes

195 were then counted at $40 \times$ magnification using a dissecting microscope. Biomass $\mathrm{N}$ of

196 protozoa and bacterivorous nematodes were calculated according to Stout \& Heal (1967) and

197 Sohlenius \& Sandor (1987), respectively. N mineralization (excretion and turnover) of

198 microfauna was calculated assuming bacterivore turnover rate of $0.16 \mathrm{~d}^{-1}$ (Zwart et al. 1994) 
199 for both nematodes and protozoans and setting yield ratios of protozoans and nematodes on

200 bacteria to 0.4 and 0.04 (Coleman et al. 1978). The total biomass of enchytraeids was

201 determined as described by Maraldo et al. (2008). The density of microarthropods was

202 determined as described by Holmstrup et al. (2007), and the biomass of dominating

203 taxonomic groups was estimated using representative values from Petersen \& Luxton (1982).

204 The pool of $\mathrm{N}$ contained in the biomass was calculated assuming nitrogen concentrations of

$20511.5 \%$ and $10 \%$ of dry weight in enchytraeids and microarthropods, respectively (Persson

206 1983). The yearly turnover rate of biomass $\mathrm{N}$ was assumed to be 1.2 for enchytraeids

207 (Standen 1973), and 1.8 for microarthropods (De Ruiter et al. 1993). The annual

208 mineralization (excretion and turnover) of $\mathrm{NH}_{4}{ }^{+}-\mathrm{N}$ by enchytraeids and microarthropods was

209 estimated based on biomass as described by Persson (1983).

210

$211 \mathrm{~N}_{2} \mathrm{O}$ emissions and $\mathrm{N}_{2} \mathrm{O}$ reductase

212 Fluxes of $\mathrm{N}_{2} \mathrm{O}$ were measured with a static chamber method using white PVC chambers

213 (height 15 or $45 \mathrm{~cm}$ depending on vegetation height) placed on metal collars $(60 \times 60 \mathrm{~cm})$

214 permanently installed in the soil. Enclosure times were 2 to $2.5 \mathrm{~h}$, during which headspace air

215 was sampled four times and later analyzed for $\mathrm{N}_{2} \mathrm{O}$ concentration by gas chromatography.

216 The $\mathrm{N}_{2} \mathrm{O}$ flux was calculated using linear regression. Nine $\mathrm{N}_{2} \mathrm{O}$ measuring campaigns

217 including all eight treatments were carried out from June 2006 to March 2007, and from April

218 to June 2007 five campaigns were conducted in five of the treatments, viz. A, $\mathrm{CO}_{2}, \mathrm{D}, \mathrm{DCO}_{2}$

219 and $\mathrm{TDCO}_{2}$. Annual cumulative $\mathrm{N}_{2} \mathrm{O}$ fluxes were derived by interpolation between

220 measurement days and by extrapolating the emission from the treatments $\mathrm{T}, \mathrm{TD}$ and $\mathrm{TCO}_{2}$ for

221 the period March- June 2007. Further methodological description is found in Carter et al.

222 (2010). 
223 To determine $\mathrm{N}_{2} \mathrm{O}$ reductase activity, nitrate was removed from sub samples of the 224 soil cores taken in November 2007 for fauna biomass estimation by vortexing $10 \mathrm{~g}$ fresh soil 225 and $30 \mathrm{ml}$ of phosphate buffered saline (PBS) for $5 \mathrm{sec}$ followed by centrifugation for $10 \mathrm{~min}$ 226 at $3500 \times \mathrm{G}$ and $5{ }^{\circ} \mathrm{C}$. The supernatant was discarded and the pellet resuspended in $30 \mathrm{ml}$ 227 PBS. After the third centrifugation the pellet was resuspended in $15 \mathrm{ml}$ of $0.5 \mathrm{mM}$ glucose, $2280.5 \mathrm{mM}$ sodium acetate, and $0.5 \mathrm{mM}$ sodium succinate and transferred to a $100 \mathrm{ml}$ incubation 229 bottle. The bottle was sealed with a butyl rubber stopper, flushed with $\mathrm{N}_{2}$ for 2 min, added $230100 \mathrm{ppm} \mathrm{N}_{2} \mathrm{O}$ (final concentration), placed horizontally on a shaker (200 rpm), and incubated 231 at $22{ }^{\circ} \mathrm{C}$. After $0,1,3,6$ and $24 \mathrm{~h}, 3 \mathrm{ml}$ of headspace was transferred to a pre-evacuated $3 \mathrm{ml}$ 232 Venoject vial before analysis of $\mathrm{N}_{2} \mathrm{O}$ by gas chromatography. The $\mathrm{N}_{2} \mathrm{O}$ reductase activity was 233 calculated from the consumption of $\mathrm{N}_{2} \mathrm{O}$ during the incubation.

\section{Nitrogen mineralization and immobilization}

236 Gross rates of $\mathrm{N}$ mineralization and immobilization were determined by the isotope pool-

237 dilution approach applied in laboratory incubations. Soil cores within each plot were sampled 238 in September 2007 (0-5 and 5-10 cm soil depth, respectively), sieved and stored at $5{ }^{\circ} \mathrm{C}$ for 239 about one week until incubations were initiated. Fresh samples (10 g) were weighed in $250 \mathrm{ml}$ 240 poly-ethylene bottles and mixed thoroughly with $400 \mu \mathrm{l}$ of a ${ }^{15} \mathrm{~N}-\mathrm{NH}_{4} \mathrm{Cl}$ solution (5 atm \% $241{ }^{15} \mathrm{~N}$ ) to provide $5 \mu \mathrm{g} \mathrm{N} \mathrm{g}^{-1}$ soil. One set of samples was analyzed immediately upon substrate 242 application, and a second set was analyzed after 7 days of incubation at $20{ }^{\circ} \mathrm{C}$. Contents of 243 mineral $\mathrm{N}$ and the ${ }^{15} \mathrm{~N}$ contents were determined upon extraction and micro-diffusion 244 (Sørensen \& Jensen 1991). Gross daily rates of mineralization and immobilization were 245 calculated according to equations given by Kirkham \& Bartholomew (1954). Upscaling to 
246 annual rates was done using the mean annual soil temperatures in $5 \mathrm{~cm}$ depth $\left(10^{\circ} \mathrm{C}\right)$ at the

247 experimental site and assuming a $Q_{10}$ of 2.

\section{Potential nitrification and denitrification}

250 Subsamples from the soil cores taken in November 2007 were gently homogenized by hand

251 and major roots were removed. Soil samples were stored at $4{ }^{\circ} \mathrm{C}$ until analysis (less than 24

252 h). Potential nitrification was determined in $3 \mathrm{~g}$ soil samples by a modification of the method 253 described by Belser \& Mays (1980) but without adding chlorate. Potential nitrification rates 254 were estimated from the increase in nitrite+nitrate concentrations. Potential denitrification 255 rates (Wolsing \& Prieme 2004) in $10 \mathrm{~g}$ soil samples were estimated from linear regression of 256 increase in headspace $\mathrm{N}_{2} \mathrm{O}$ concentration during 180 min incubation.

Water percolation and nitrogen leaching

259 Leachate water was collected monthly from passive PVC soil water draining collectors below 260 the organic soil layer (approximately $5 \mathrm{~cm}$ depth) and polytetrafluoroethylene (PTFE) suction 261 cups with continuous sub-atmospheric pressure (Prenart Super Quarz, Frederikberg, DK) 262 below the main rooting zone (60 cm depth). Concentrations of $\mathrm{NH}_{4}{ }^{+}-\mathrm{N}, \mathrm{NO}_{3}{ }^{-}-\mathrm{N}$, and total $\mathrm{N}$ 263 (by UV-persulphate oxidation) were analyzed on an Autoanalyzer 3 (Bran+Luebbe Gmbh, 264 Germany). DON was calculated as total N minus inorganic N. Precipitation was measured at 265 the site and the volume of percolating water was estimated by simulation with the CoupModel 266 model (Jansson \& Moon 2001; Svensson et al. 2008) - a coupled ecosystem model with a 267 balance of abiotic and biotic processes in the soil-plant-atmosphere system. The basic 268 structure of the model is a depth profile of the soil, and calculations of water and heat flows 
269 are based on common soil properties. The model was parameterised using measured soil layer 270 properties and against time series of soil temperature and moisture content, using on site 271 measurements of radiation, precipitation and wind speed as driving data and a generalised

272 likelihood uncertainty evaluation approach. Percolation of water below $60 \mathrm{~cm}$ was calculated 273 as an output of the simulations and leaching of nitrogen at that depth was calculated as the 274 product of the sum of water percolation and the concentration measured in the soil water for 275 each water collection period (Schmidt et al. 2004).

277 Statistical analyses

278 Statistical analyses were conducted using the multiple linear regression procedure PROC

279 MIXED of SAS (SAS Institute 2003). The statistical model included a random statement that 280 accounted for the experimental design (Random Block octagon octagon*D octagon*T). The 281 same model was used for all tested variables and included the three main factor effects $\left(\mathrm{CO}_{2}\right.$, $282 \mathrm{D}$, and $\mathrm{T})$ as well as all possible interactions $\left(\mathrm{D} * \mathrm{CO}_{2}, \mathrm{~T}^{*} \mathrm{CO}_{2}, \mathrm{~T} * \mathrm{D}\right.$, and $\left.\mathrm{T}^{*} \mathrm{D} * \mathrm{CO}\right) . \mathrm{P}$-values $283 \leq 0.05$ were considered significant. Data were transformed when necessary to obtain 284 normality and homogeneity of variance. Differences of Least Squares Means (DLSM) were 285 used to interpret significant treatment interactions. During the DLSM evaluation, each 286 significant interaction was categorized as either antagonistic, i.e. the combined effect led to a 287 reduction of the observed individual effects or synergistic, i.e. the combined effect led to 288 either a) an amplification of the observed individual effect(s) or b) to a significant effect only 289 when treatments were combined. The DLSM evaluation also revealed if interactions were due 290 to significant single treatment effects, i.e. effects observe in single treatment plots only, which 291 disappear in combination with other treatments. Furthermore, DLSM evaluation of significant 292 interactions revealed if significant main factor effects were effects observed only when in 
293 combination with other treatments or if it was significant also as a single treatment effect.

294 Finally, we noted simple additive effects when two of the treatments both showed significant

295 main factor effects but with no interactions. 


\section{Results}

\section{Ecosystem $N$ balance}

299 The $\mathrm{N}$ cycle at the site is dominated by higher internal $\mathrm{N}$ turnover in comparison to the inputs 300 and losses by leaching and gaseous emission to the atmosphere (Fig. 1). Gross mineralization 301 $\left(6.7 \pm 0.96 \mathrm{~g} \mathrm{~N} \mathrm{~m}^{-2} \mathrm{y}^{-1}\right)$ is five times higher than bulk deposition $\left(1.35 \pm 0.04 \mathrm{~g} \mathrm{~N} \mathrm{~m}^{-2} \mathrm{y}^{-1}\right)$, an 302 order of magnitude higher than losses by leaching $\left(0.80 \pm 0.37 \mathrm{~g} \mathrm{~N} \mathrm{~m}^{-2} \mathrm{y}^{-1}\right)$ and two orders of 303 magnitude higher than gaseous losses in form of $\mathrm{N}_{2} \mathrm{O}\left(0.031 \pm 0.006 \mathrm{~g} \mathrm{~N} \mathrm{~m}^{-2} \mathrm{y}^{-1}\right)$. Negligible $304 \quad \mathrm{~N}_{2} \mathrm{O}$ reductase activity was observed in the soil samples with $\mathrm{N}_{2} \mathrm{O}$ uptake rates less than $1 \mathrm{ng}$ $305 \mathrm{~N} \mathrm{~g}^{-1} \mathrm{dw} \mathrm{h}{ }^{-1}$ in all samples and $\mathrm{N}_{2}$ production is therefore assumed to be negligible (data not shown). Above ground, about $90 \%$ of $\mathrm{N}$ is found in the two dominant species Calluna ( 60 $\%)$ and Deschampsia ( 30 \%). Below ground, most N is stored in the SOM pool ( 90\%) with Deschampsia roots $(\sim 4 \%)$, Calluna roots $(\sim 3 \%)$ and soil microbial $(\sim 1.5 \%)$ pools

309 dominating the remaining fraction. Soil fauna biomass was $\sim 10 \%$ of microbial biomass but 310 their mineralization of $\mathrm{N}$ is estimated to $5.0 \pm 0.6 \mathrm{~g} \mathrm{NH}_{4}{ }^{+}-\mathrm{N} \mathrm{m}^{-2} \mathrm{y}^{-1}$, i.e. an amount of labile $\mathrm{N}$ 311 much larger than the $\mathrm{N}$ input to the system by $\mathrm{N}$ bulk deposition. The system retained $0.53 \mathrm{~g}$ $312 \mathrm{~N} \mathrm{~m}^{-2} \mathrm{y}^{-1}$ of bulk deposition in the ambient, non-manipulated plots in 2007 as estimated by 313 difference between bulk deposition and sum of total $\mathrm{N}$ leaching below $60 \mathrm{~cm}$ soil depth and $314 \mathrm{~N}_{2} \mathrm{O}$ emission. While bulk deposition in $2006\left(1.27 \pm 0.07 \mathrm{~g} \mathrm{~N} \mathrm{~m}^{-2} \mathrm{y}^{-1}\right)$ was similar to the 315 deposition in $2007\left(1.35 \pm 0.04 \mathrm{~g} \mathrm{~N} \mathrm{~m}^{-2} \mathrm{y}^{-1}\right)$, total $\mathrm{N}$ leaching across all treatments was 316 significantly lower $(\mathrm{P}<0.0001)$ in $2006\left(0.13 \pm 0.06 \mathrm{~g} \mathrm{~N} \mathrm{~m}^{-2} \mathrm{y}^{-1}\right)$ than in $2007(0.56 \pm 0.20 \mathrm{~g}$

$317 \mathrm{~N} \mathrm{~m}^{-2} \mathrm{y}^{-1}$ ) with no significant treatment effects in either 2006 (data not shown) or in 2007 318 (Table 1). The major cause of this interannual difference was a wet summer in 2007 (202 mm 
319 precipitation in July) with extensive leaching compared to a dry summer in 2006 (60 mm 320 precipitation in July) when summer leaching was absent.

Plant responses to climate manipulations

323 The above-ground biomass $\mathrm{N}$ of the dominant plant species Calluna and Deschampsia did not

324 respond to the climate manipulations (Table 1). Root biomass $\mathrm{N}$ of Deschampsia was also 325 unaffected by the treatments, whereas root biomass $\mathrm{N}$ of Calluna increased in response to 326 drought (Table $1, \mathrm{P}=0.04$ ) indicating a change in the root:shoot $\mathrm{N}$ allocation pattern. While

$327 \mathrm{~N}$ in above-ground biomasses were unaffected by treatments, the $\mathrm{C} / \mathrm{N}$ ratios of Calluna

328 flowers as well as leaves from both Calluna and Deschampsia increased in response to 329 elevated $\mathrm{CO}_{2}$ (Table $1, \mathrm{P}=0.02,0.04$, and 0.01 , respectively). The evaluation by DLSM of 330 the three-way interaction for the $\mathrm{C} / \mathrm{N}$ ratio of mosses (Table $1, \mathrm{P}=0.003$ ) showed that the 331 interaction was due to significantly higher $\mathrm{C} / \mathrm{N}$ ratios in the single treatments of drought and 332 elevated $\mathrm{CO}_{2}$, while ratios were unchanged when drought and elevated $\mathrm{CO}_{2}$ were combined 333 with each other as well as when they were combined with warming. The observed increases in $334 \mathrm{C} / \mathrm{N}$ ratios in new plant tissue of leaves and flowers were not seen in whole-plant $\mathrm{C} / \mathrm{N}$ ratios 335 of Deschampsia or in the green tissue or wood fractions of Calluna. Yet, the N concentration 336 of Deschampsia litter decreased under elevated $\mathrm{CO}_{2}$ (Table $\left.1, \mathrm{P}=0.05\right)$, indicating that the 337 changes in $\mathrm{C} / \mathrm{N}$ ratios starting in the leaves, are already beginning to cascade through the 338 system, after only two years of treatments (Fig. 2a). Deschampsia leaves and also mosses (single treatment only) responded to drought with increased $\mathrm{C} / \mathrm{N}$ ratios (Table $1, \mathrm{P}=0.002$ and $\mathrm{P} \leq 0.05$, respectively) whereas Calluna

341 leaves were unaffected (Table 1, Fig. 2b). Also, the pool of $\mathrm{N}$ in the annually produced

342 Deschampsia litter decreased in response to drought (Table $1, \mathrm{P}=0.01$ ). The warming 
343 treatment had fewer effects on above-ground processes than the other treatments, showing 344 only an increase of $\mathrm{N}$ concentration in Deschampsia litter (Table 1, P =0.03, Fig 2c).

When all treatments were combined (Fig. 2d), the lack of interactions between single treatment effects for leaf level $\mathrm{C} / \mathrm{N}$ ratios indicates that the effect is found also in treatment combinations. Consequently, increased $\mathrm{C} / \mathrm{N}$ ratios of leaves as well as decreased

Deschampsia litter $\mathrm{N}$ production are found in the full combination of treatments, i.e. in the

simulation of the projected future climate scenario. In contrast, the $\mathrm{C} / \mathrm{N}$ ratio of mosses increases in two of the three single treatments and N concentrations in Deschampsia litter either increase or decrease depending on treatment but these effects disappear when all treatments are combined.

\section{Responses of below-ground processes to climate manipulations}

The below-ground $\mathrm{N}$ turnover was significantly affected by the climate manipulations, ground but the analysis of DLSM when evaluating the interactions revealed reductions in leachate concentrations in $5 \mathrm{~cm}$ soil depth of $\mathrm{NO}_{3}{ }^{-} \mathrm{N}, \mathrm{NH}_{4}{ }^{+}-\mathrm{N}$ and DON (Table 1, Fig. 3a) in the single $\mathrm{CO}_{2}$ treatment. These effects were reduced when elevated $\mathrm{CO}_{2}$ was combined with other treatments causing the significant interactions for these three variables (Table 1).

The drought treatment reduced the $\mathrm{N}$ pools of enchytraeids and protozoans and their mineralization (Table $1, \mathrm{P}=0.03$ ), and reduced the pool of $\mathrm{NH}_{4}{ }^{+}-\mathrm{N}$ (Table $1, \mathrm{P}=0.02$ ), thus

365 indicating an overall decrease in the $\mathrm{N}$ turnover in response to drought (Fig. 3b). In contrast, warming stimulated microbial ammonium consumption in the top $5 \mathrm{~cm}$ of soil (Table $1, \mathrm{P}=$ 
3670.04 ) as well as the gross mineralization rate (single treatment only, Table $1, \mathrm{P} \leq 0.05$ ) and

368 nitrification rates (Table $1, \mathrm{P}=0.004$ ), leading to both increased denitrification (Table $1, \mathrm{P}=$ 3690.02 ) and $\mathrm{N}_{2} \mathrm{O}$ emission (Table $1, \mathrm{P}=0.05$ ). Overall, the below-ground response to the

370 warming treatments was therefore an increase in $\mathrm{N}$ turnover (Fig. 3c).

371 While no direct main effects of elevated $\mathrm{CO}_{2}$ were observed, it influenced the

372 responses to drought and warming primarily by reducing some of the significant individual

373 effects in the three-factor combination. Still, the drought-induced decrease of fauna-N and

374 fauna $\mathrm{N}$ mineralization as well as the warming-induced increased denitrification did not

375 interact significantly with the other treatments and consequently remained in the full

376 treatment combination.

$378 \quad$ Interactions between climate manipulations

379 Across the 47 variables reported (Table 1) the drought treatment lead to the highest number of 380 significant main effects (11) followed by warming and $\mathrm{CO}_{2}$ treatments ( 6 and 4 , respectively).

381 Simultaneously there were a large number of interactions between the three treatments (14).

382 Interestingly, the analysis of the interactions revealed a dominance of antagonistic effects

383 (Fig. 4) with more than twice as many antagonistic effects as synergistic effects. Furthermore, 384 simple additive effects were less frequent than both antagonistic and synergistic effects. 


\section{Discussion}

387

Overall ecosystem $N$ turnover

388 The $\mathrm{N}$ cycle at the experimental site is characterized by higher internal $\mathrm{N}$ turnover than bulk $389 \mathrm{~N}$ deposition and losses by leaching and $\mathrm{N}_{2} \mathrm{O}$ production as generally seen in natural and 390 semi-natural ecosystems. In comparison to our estimated annual gross mineralization rate (6.7 $391 \pm 0.96 \mathrm{~g} \mathrm{~N} \mathrm{~m}^{-2} \mathrm{y}^{-1}$ ), Emmett et al. (2004) reported net mineralization rates of 3.8 to $6.6 \mathrm{~g} \mathrm{~N} \mathrm{~m}^{-}$ $392{ }^{2} y^{-1}$ from another Danish dry heathland and Aerts (1993) reported rates ranging from 4.4 to $393 \quad 12.6 \mathrm{~g} \mathrm{~N} \mathrm{~m}^{-2} \mathrm{y}^{-1}$ under different plant species in wet and dry Dutch heathlands, where 394 atmospheric deposition is 2-3 times higher than in Denmark. Inter-annual variability in N 395 leaching was significant, while treatment differences after two years of treatments were not 396 significant. The observed difference in leaching between 2006 and 2007 shows that the 397 ecosystem $\mathrm{N}$ loss by leaching is highly dependent on the amount and timing of precipitation. 398 In a future climate with more precipitation distributed in fewer, but more severe rain events, $\mathrm{N}$ 399 leaching is likely to increase in this ecosystem. The inter-annual variability in leaching may 400 also indicate that the ecosystem is close to $\mathrm{N}$ saturation as also suggested from an adjacent 401 short-term experiment where $\mathrm{N}$ and phosphorus $(\mathrm{P})$ addition resulted in only a modest 402 increase in fine root biomass of Deschampsia, and no effects on Calluna roots (Nielsen et al. 403 2009). Furthermore, Deschampsia responded more when both $\mathrm{N}$ and $\mathrm{P}$ were added indicating 404 that this species is currently more limited by $\mathrm{P}$ than $\mathrm{N}$ availability. If nitrogen availability 405 should decrease due to progressive nitrogen limitation as the treatment exposure continues, 406 this, in combination with the P limitation for Deschampsia, would be beneficial to the slower 407 growing Calluna. However, other climate factors, i.e. water availability and temperature 
408 increase, are likely to influence the overall competitive relationship, potentially disturbing the 409 balance of the equilibrium, especially if the rates of mortality of Calluna are increased.

410 The mineralization of $\mathrm{NH}_{4}{ }^{+}-\mathrm{N}$ by soil fauna is often neglected but contributes 411 significantly to the pool of plant available $\mathrm{N}$ in the soil (Osler \& Sommerkorn 2007). In the 412 present study, we calculated fauna $\mathrm{N}$ mineralization from estimated biomasses and literature 413 values of the turnover times and yields of microfauna and mesofauna. Obviously, upscaling of 414 e.g. enumeration of bacterivorous protozoa and nematodes to gross nitrogen mineralization 415 should be evaluated with caution. Values for bacterivore biomass, turnover, and growth yield 416 on bacteria are all needed to perform the upscaling and very few references exist in the 417 literature on such values. This said, the value for fauna-related $\mathrm{N}$ mineralization in the 418 ambient treatment based on this calculation seems trustworthy based on the gross $\mathrm{N}$ 419 mineralization from the pool dilution assay of $6.7 \mathrm{~g} \mathrm{~N} \mathrm{~m}^{-2} \mathrm{y}^{-1}$. The assumption that most 420 bacterial mineralization is facilitated through predation and mineralization by the soil fauna 421 implies that $\mathrm{N}$ mineralization by bacteria is responsible for approximately $75 \%$ of the total 422 activity, the rest being due to fungi.

Responses to elevated $\mathrm{CO}_{2}$, warming and drought

425 Elevated atmospheric $\mathrm{CO}_{2}$ concentration is known to induce down-regulation of

426 photosynthetic capacity, e.g. via reduced content of Rubisco in the leaves (Ainsworth \& Long 427 2005; Ainsworth \& Rogers 2007) and reduction of leaf nitrogen content and increased C/N 428 ratios of leaves (Paterson et al. 1999; Lutze \& Gifford 2000; van Heerwaarden et al. 2005; 429 Finzi et al. 2006; Chen et al. 2007; Hovenden et al. 2008). At our experimental site, we 430 observed reduced photosynthetic capacity (Albert et al. 2010) and leaf nitrogen under 431 elevated $\mathrm{CO}_{2}$ for the dominant species, Calluna and Deschampsia, as well as increased leaf 
$432 \mathrm{C} / \mathrm{N}$ ratios. However, the increased $\mathrm{C} / \mathrm{N}$ ratios observed in leaves, and for Calluna also

433 observed in flower biomass were after two years of treatments not large enough to affect

434 whole plant biomass $\mathrm{C} / \mathrm{N}$ ratios, which were not affected by the treatments. Previous studies

435 have found increasing $\mathrm{C} / \mathrm{N}$ ratios in other plant tissues than leaves (McGuire et al. 1995;

436 Cotrufo et al. 1998), but the change often is much weaker than that observed for leaves

437 (McGuire et al. 1995), indicating that the $\mathrm{C} / \mathrm{N}$ effect of elevated $\mathrm{CO}_{2}$ is closely linked to the 438 processes involved in the carbon sequestration in the photosynthetic apparatus (Körner 2000).

439 As hypothesized, however, N concentration in Deschampsia litter after two years of

440 treatments was also reduced by elevated $\mathrm{CO}_{2}$, possibly showing that the effect is beginning to

441 cascade from leaf level to other ecosystem $\mathrm{N}$ pools, although the effect disappears in the full

442 treatment combination. Together with the observed increased concentration of tannins

443 (Schmidt et al. 2007) in plant tissues, we anticipate that the changes in $\mathrm{C} / \mathrm{N}$ ratios will affect

444 litter decomposition rates as the experimental treatments continue.

In contrast to our expectations, the above- and below-ground plant $\mathrm{N}$ pools were not increased by elevated $\mathrm{CO}_{2}$. However, total root biomass $\mathrm{N}$ of Calluna increased unexpectedly in response to drought. It is inherently difficult to estimate total roots from small soil samples due to the large spatial heterogeneity in root distribution and, at the same time, collection of

449 larger samples is problematic due to the destruction of the experimental plots. We are

450 therefore reluctant to put too much emphasis on this result and conclude overall that total 451 biomass $\mathrm{N}$ of both dominant species as well as mosses after two years of treatments were only 452 marginally affected by the applied climate drivers.

Increased rhizodeposition is a common plant response to elevated $\mathrm{CO}_{2}$ (Pendall et al. 2004; Allard et al. 2006), and strong effects on below-ground C cycling have been observed in response to elevated $\mathrm{CO}_{2}$ in the current experiment, e.g. increased soil respiration rates 
457 2010a). However, in contrast to our expectation, we observed very few direct effects of

458 elevated $\mathrm{CO}_{2}$ on below-ground $\mathrm{N}$ processes. Still, the decreased concentrations of organic and 459 inorganic $\mathrm{N}$ leachate water at $5 \mathrm{~cm}$ soil depth imply that mineralization processes are affected 460 or possibly that root $\mathrm{N}$ uptake has increased. In contrast to the lack of direct changes in 461 response to elevated $\mathrm{CO}_{2}$, soil processes were more sensitive to the drought and warming 462 treatments. Our study supports previous observations of increased below-ground N turnover 463 in response to warming (Rustad et al. 2001; Schmidt et al. 2004). We observed increased 464 microbial $\mathrm{NH}_{4}{ }^{+}-\mathrm{N}$ consumption, gross mineralization, potential nitrification, and 465 denitrification from lab incubations of soils, as well as increased in situ $\mathrm{N}_{2} \mathrm{O}$ emissions. Soil 466 and litter incubations in situ also showed that warming promoted $\mathrm{N}$ cycling (Andresen et al. 467 2010b). Previous field studies with artificial warming also showed no warming effect on $\mathrm{N}_{2} \mathrm{O}$ 468 emission rates (Peterjohn et al. 1994; Mchale et al. 1998). However, we interpret our 469 observation of five variables that all responded in the same direction to warming as a strong 470 indicator that the warming effect on $\mathrm{N}$ turnover was real.

471 The below-ground $\mathrm{N}$ turnover was reduced by drought as observed by reduced gross

$472 \mathrm{~N}$ mineralization and fauna $\mathrm{N}$ mineralization. Reduced $\mathrm{N}$ mineralization in response to 473 drought has previously been observed (Emmett et al. 2004; Schmidt et al. 2004; Sowerby et 474 al. 2008) but the negative effects of drought on $\mathrm{N}$ mineralization are often attributed directly 475 to reduced microbial activity. The importance of soil fauna to the $\mathrm{N}$ mineralization shown in 476 this study, together with the negative effects of drought on top soil layer populations of 477 enchytraeids (Maraldo et al. 2010) and other fauna groups and their decreased $\mathrm{N}$ 478 mineralization rates, indicate that the fauna response plays a significant role in the observed 479 decrease in $\mathrm{N}$ turnover in drought-exposed plots. Furthermore, while the warming effects 480 were generally reduced in combination with drought and elevated $\mathrm{CO}_{2}$, the negative effect of 481 drought on fauna $\mathrm{N}$ biomass and $\mathrm{N}$ mineralization was not reduced by interactions. 
482 Consequently, the effect prevailed in the full combination of treatments, indicating that $\mathrm{N}$

483 mineralization will be reduced in the full future climate scenario. Therefore, despite the fact

484 that this ecosystem currently show no clear sign of $\mathrm{N}$ limitation of plant growth, we cannot

485 rule out the possibility that progressive nitrogen limitation will play a role in the longer term,

486 as the impacts of increased $\mathrm{CO}_{2}$ on $\mathrm{C} / \mathrm{N}$ ratios of leaves combined with the drought induced

487 reduction of mineralization and litter $\mathrm{N}$ production continues to reduce the availability of $\mathrm{N}$ in 488 the ecosystem.

489

Importance of climate driver interactions

491 We thoroughly investigated the background for all significant interactions observed in the 47

492 variables reported in Table 1 by evaluating the DLSM from the mixed model statistical

493 output. This analysis revealed a clear dominance of antagonistic effects over synergistic and

494 simple additive effects when several treatments were combined (Table 1 and Fig. 4), i.e. the

495 ecosystem is more robust when more than one factor is changed. For instance, the $\mathrm{C} / \mathrm{N}$ ratio

496 of mosses increased in both single treatments of drought and elevated $\mathrm{CO}_{2}$ but was unaffected

497 when treatments were combined. Similarly, the increased gross mineralization rate observed

498 in the single warming treatment was reduced especially in combination with elevated $\mathrm{CO}_{2}$.

499 Furthermore, two of the three additive effects observed (Deschampsia litter N concentration

500 and $\mathrm{N}_{2} \mathrm{O}$ emissions) were additive responses with opposing directions, which therefore acts to

501 reduce the observed effects in treatment combinations.

Previous studies have investigated interactions between elevated $\mathrm{CO}_{2}$ and e.g. $\mathrm{N}$

503 supply (Lutze \& Gifford 2000; Lutze et al. 2000; van Heerwaarden et al. 2005; Reich et al.

504 2006), warming (Peltola et al. 2002; Tingey et al. 2003; Hovenden et al. 2008; Dijkstra et al.

505 2010), biodiversity (Reich et al. 2001; Niklaus et al. 2001) and water relations (Morgan et al. 
506 2004; Nowak et al. 2004). A review by Barnard et al. (2005) of 25 multi-factor studies

507 concluded that interactions were generally rare. These 25 studies were dominated by

508 experimentally elevated $\mathrm{CO}_{2}$ combined with increased $\mathrm{N}$ supply. The lack of interactions

509 could be due to the common trend that most ecosystems respond strongly to increased $\mathrm{N}$

510 supply, which hides weaker interactive responses. Luo et al. (2008) analyzed and modeled

511 interactions between elevated $\mathrm{CO}_{2}$, warming and changes in precipitation in 7 multi-factor

512 studies and found that three-way interactions were rare while two-way interactions were more

513 common. Generally, interactions were positive between elevated $\mathrm{CO}_{2}$ and warming and

514 negative between elevated $\mathrm{CO}_{2}$ and reduced precipitation with respect to net primary

515 production (NPP).

516 A general pattern of most published studies is the focus on a few important variables,

517 i.e. overall changes in NPP or biomasses or specific studies focusing on processes, e.g.

518 nitrification and denitrification. As interactions are only sometimes significant, investigating a

519 small number of variables prevents a more general interpretation of the importance of

520 interactions. Furthermore, assuming that three-way interactions are more uncommon than

521 two-way interactions, important three-way interactions could be missed when fewer variables

522 are analyzed. Out of 14 interactions observed across $47 \mathrm{~N}$ related variables in the present

523 study, 5 were three-way interactions. This suggests that insufficient interactions between

524 elevated $\mathrm{CO}_{2}$, warming and changes in precipitation were included in the ecosystem models

525 applied by Luo et al. (2008) and reinforces the need for further multi-factor ecosystem

526 manipulation experiments focusing on interactive effects.

527 When analyzing the interactions, we found a predominance of antagonism in the

528 combined responses. The consequence of the dominance of antagonistic interactions in

529 combined climate driver responses is that ecosystem changes caused by climate change may

530 be less pronounced than judged from single factor experiments. Based on these results we 
1

2

3

4

5

6

7

8 9

531 raise the hypothesis that combined effects of all future climate change are dampened

532 compared to expected effects based on simple addition of single treatment responses. If this

533 pattern prevails for ecosystem responses to future climate change in general it highlights 1)

534 that single factor studies are likely to overestimate responses and should be evaluated with

535 caution, and 2) that multi-factor field-scale ecosystem experiments are critical in order to be

536 able to predict realistic response strengths as well as for developing a conceptual framework

537 for understanding interactions among climate drivers. Our multi-variable approach may aid

538 the latter point if tested in other multi-factor studies and by including variables not only

539 constraint to the nitrogen cycle. 


\section{Conclusions}

542 The drought treatment effects dominated over effects of warming and elevated $\mathrm{CO}_{2}$ in

543 observed responses of the nitrogen cycle after two years of treatments. In contrast to our

544 expectations, we did not observe increased growth of the $\mathrm{N}$ pools of the dominant plant

545 species, Calluna and Deschampsia in response to elevated $\mathrm{CO}_{2}$. While previous studies have

546 usually found interactions to be rare, interactions were commonly observed and antagonism

547 dominated over synergism in combined responses, i.e. the ecosystem response to the

548 combination of several climate drivers is dampened compared to single treatment responses.

549 Still, the observed negative response to drought of soil fauna biomass and $\mathrm{N}$ mineralization

550 and Deschampsia litter N production prevailed in the full treatment combination and so did

551 the increased leaf $\mathrm{C} / \mathrm{N}$ ratios of the dominant species Calluna and Deschampsia. If persistent,

552 these changes are likely to lead to reduced $\mathrm{N}$ availability and possibly to progressive nitrogen

553 limitation as the experimental treatments continue. 


\section{4}

555 Acknowledgements

556 We wish to thank Preben Jørgensen and Poul Sørensen for their great efforts in maintaining

557 the CLIMAITE field site. We gratefully acknowledge Claus Thorn Ekstrøm and Anders

558 Tolver Jensen for their help with the statistical model setup and statistical output

559 interpretation. The CLIMAITE experiment is sponsored by the Villum Kann Rasmussen

560 foundation with substantial co-funding from Air Liquide, DONG Energy and SMC Pneumatic

561 A/S. Measurements of $\mathrm{N}_{2} \mathrm{O}$ emissions were part of NitroEurope IP funded by the European

562 Commission. 


\section{Reference List}

565 Aerts R (1993) Biomass and nutrient dynamics of dominant plant species from heathlands. In:

566 Heathlands: Patterns and Processes in a Changing Environment (eds Aerts R, Heil GW), pp.

567 51-84. Kluwer Academic Publishers, Dordrecht, The Netherlands.

568 Ainsworth EA, Long SP (2005) What have we learned from 15 years of free-air $\mathrm{CO}_{2}$

569 enrichment (FACE)? A meta-analytic review of the responses of photosynthesis, canopy. New $570 \quad$ Phytologist, 165, 351-371.

571 Ainsworth EA, Rogers A (2007) The response of photosynthesis and stomatal conductance to 572 rising $\left[\mathrm{CO}_{2}\right]$ : mechanisms and environmental interactions. Plant Cell and Environment, 30, $573 \quad 258-270$.

574 Albert KR, Ro-Poulsen H, Mikkelsen TN, Michelsen A, Beier C (2010) Water status interacts 575 strongly with the effect of elevated $\mathrm{CO}_{2}$, warming and drought episodes on plant carbon 576 uptake in a temperate heath ecosystem. Submitted July 2010 to Plant Cell Environment.

577 Allard V, Robin C, Newton PCD, Lieffering M, Soussana JF (2006) Short and long-term 578 effects of elevated $\mathrm{CO}_{2}$ on Lolium perenne rhizodeposition and its consequences on soil 579 organic matter turnover and plant N yield. Soil Biology \& Biochemistry, 38, 1178-1187.

580 Andresen, L. C., Michelsen, A., Ambus, P., and Beier, C. (2010a) Belowground heathland 581 responses after 2 years of combined warming, elevated $\mathrm{CO}_{2}$ and summer drought.

582 Biogeochemistry, in press. 
583 Andresen LC, Michelsen A, Jonasson S, Schmidt IK, Mikkelsen TN, Ambus P, Beier C

584 (2010b) Plant nutrient mobilization in temperate heathland responds to elevated $\mathrm{CO}_{2}$,

585 temperature and drought. Plant and Soil, 328, 381-396.

586 Barnard R, Leadley PW, Hungate BA (2005) Global change, nitrification, and denitrification:

587 A review. Global Biogeochemical Cycles, 19, 1-13, DOI: 10.1029/2004GB002282.

588 Belser LW, Mays EL (1980) Specific-Inhibition of Nitrite Oxidation by Chlorate and Its Use 589 in Assessing Nitrification in Soils and Sediments. Applied and Environmental Microbiology, $590 \quad 39,505-510$.

591 Carter MS, Ambus P, Albert K, et al (2010) Effects of elevated atmospheric $\mathrm{CO}_{2}$, prolonged 592 summer drought and temperature increase on $\mathrm{N}_{2} \mathrm{O}$ and $\mathrm{CH}_{4}$ fluxes in a temperate heathland. 593 Submitted July 2010 to Biogeochemistry.

594 Chen X, Tu C, Burton MG, Watson DM, Burkey KO, Hu SJ (2007) Plant nitrogen acquisition 595 and interactions under elevated carbon dioxide: impact of endophytes and mycorrhizae.

596 Global Change Biology, 13, 1238-1249.

597 Coleman DC, Anderson RV, Cole CV, Elliott ET, Woods L, Campion MK (1978) Trophic 598 Interactions in Soils As They Affect Energy and Nutrient Dynamics .4. Flows of Metabolic 599 and Biomass Carbon. Microbial Ecology, 4, 373-380.

600 Cotrufo MF, Ineson P, Scott A (1998) Elevated $\mathrm{CO}_{2}$ reduces the nitrogen concentration of 601 plant tissues. Global Change Biology, 4, 43-54. 
603 Darbyshire JF, Wheatley RE, Greaves MP, Inkson RHE (1974) Rapid micromethod for 604 estimating bacterial and protozoan populations in soil. Revue D Ecologie et de Biologie du 605 Sol, 11, 465-475.

606 Davidson EA, Stark JM, Firestone MK (1990) Microbial production and consumption of 607 nitrate in an annual grassland. Ecology, 71, 1968-1975.

608 de Graaff MA, van Groenigen KJ, Six J, Hungate B, van Kessel C (2006) Interactions 609 between plant growth and soil nutrient cycling under elevated $\mathrm{CO}_{2}$ : a meta-analysis. Global 610 Change Biology, 12, 2077-2091.

611 De Ruiter PC, Moore JC, Zwart KB, et al. (1993) Simulation of nitrogen mineralization in the 612 belowground food webs of 2 winter-wheat fields. Journal of Applied Ecology, 30, 95-106.

613 Dijkstra FA, Blumenthal D, Morgan JA, Pendall E, Carrillo Y, Follett RF (2010) Contrasting 614 effects of elevated $\mathrm{CO}_{2}$ and warming on nitrogen cycling in a semiarid grassland. New 615 Phytologist, 187, 426-437.

616 Emmett BA, Beier C, Estiarte M, et al. (2004) The response of soil processes to climate 617 change: Results from manipulation studies of shrublands across an environmental gradient. 618 Ecosystems, 7, 625-637.

619 Finzi AC, Moore DJP, DeLucia EH, et al. (2006) Progressive nitrogen limitation of 620 ecosystem processes under elevated $\mathrm{CO}_{2}$ in a warm-temperate forest. Ecology, 87, 15-25.

621 Georgieva S, Christensen S, Petersen H, Gjelstrup P, Thorup-Kristensen K (2005) Early 622 decomposer assemblages of soil organisms in litterbags with vetch and rye roots. Soil Biology 623 \& Biochemistry, 37, 1145-1155. 
624 Holmstrup M, Maraldo K, Krogh PH (2007) Combined effect of copper and prolonged 625 summer drought on soil Microarthropods in the field. Environmental Pollution, 146, 525-533.

626 Hovenden MJ, Newton PCD, Carran RA, et al. (2008) Warming prevents the elevated $\mathrm{CO}_{2^{-}}$ 627 induced reduction in available soil nitrogen in a temperate, perennial grassland. Global 628 Change Biology, 14, 1018-1024.

629 Hungate BA (1999) Ecosystem responses to rising atmospheric $\mathrm{CO}_{2}$ : Feed backs through the 630 nitrogen cycle. In: Carbon dioxide and environmental stress (eds Luo YQ, Mooney HA), pp. 631 265-285. Academic Press, San Diego, USA.

632 IPCC (2007) Climate Change 2007: The Physical Science Basis. Contribution of Working 633 Group I to the Fourth Assessment Report of the Intergovernmental Panel on Climate Change. 634 (eds Solomon S, Qin D, Manning M et al.), pp. 1-996. Cambridge University Press, 635 Cambridge, UK and New York, NY, USA.

636 Jamieson N, Monaghan R, Barraclough D (1999) Seasonal trends of gross N mineralization in 637 a natural calcareous grassland. Global Change Biology, 5, 423-431.

638 Jansson PE, Moon DS (2001) A coupled model of water, heat and mass transfer using object 639 orientation to improve flexibility and functionality. Environmental Modelling \& Software, 16, $640 \quad 37-46$.

641 Jonasson S (1988) Evaluation of the Point Intercept Method for the Estimation of Plant 642 Biomass. Oikos, 52, 101-106.

643 Jonasson S, Michelsen A, Schmidt IK, Nielsen EV, Callaghan TV (1996) Microbial biomass $644 \mathrm{C}, \mathrm{N}$ and $\mathrm{P}$ in two arctic soils and responses to addition of NPK fertilizer and sugar: 645 implications for plant nutrient uptake. Oecologia, 106, 507-515. 
646 Kirkham D, Bartholomew WV (1954) Equations for following nutrient transformations in 647 soil, utilizing tracer data. Soil Science Society of America Proceedings, 18, 33-34.

648 Kongstad J, Schmidt IK, Riis-Nielsen T, Beier C, Arndal MF, Mikkelsen TN (2010) Species

649 specific responses in plant growth to changes in temperature, drought and $\mathrm{CO}_{2}$ in

650 combination: results from the CLIMAITE experiment. Submitted May 2010 to Global

651 Change Biology.

652 Körner C (2000) Biosphere responses to $\mathrm{CO}_{2}$ enrichment. Ecological Applications, 10, 15906531619.

654 Leuzinger S, Körner C (2007) Water savings in mature deciduous forest trees under elevated $655 \mathrm{CO}_{2}$. Global Change Biology, 13, 2498-2508.

656 Lipson D, Näsholm T (2001) The unexpected versatility of plants: organic nitrogen use and 657 availability in terrestrial ecosystems. Oecologia, 128, 305-316.

658 Lukewille A, Wright RF (1997) Experimentally increased soil temperature causes release of 659 nitrogen at a boreal forest catchment in southern Norway. Global Change Biology, 3, 13-21.

660 Luo Y, Su B, Currie WS, et al. (2004) Progressive nitrogen limitation of ecosystem responses 661 to rising atmospheric carbon dioxide. BioScience, 54, 731-739.

662 Luo YQ, Gerten D, Le Maire G, et al. (2008) Modeled interactive effects of precipitation, 663 temperature, and $\left[\mathrm{CO}_{2}\right]$ on ecosystem carbon and water dynamics in different climatic zones. 664 Global Change Biology, 14, 1986-1999.

665 Luo YQ, Hui DF, Zhang DQ (2006) Elevated $\mathrm{CO}_{2}$ stimulates net accumulations of carbon and 666 nitrogen in land ecosystems: A meta-analysis. Ecology, 87, 53-63. 
667 Lutze JL, Gifford RM (2000) Nitrogen accumulation and distribution in Danthonia

668 richardsonii swards in response to $\mathrm{CO}_{2}$ and nitrogen supply over four years of growth. Global 669 Change Biology, 6, 1-12.

670 Lutze JL, Gifford RM, Adams HN (2000) Litter quality and decomposition in Danthonia 671 richardsonii swards in response to $\mathrm{CO}_{2}$ and nitrogen supply over four years of growth. Global 672 Change Biology, 6, 13-24.

673 Maraldo K, Schmidt IK, Beier C, Holmstrup M (2008) Can field populations of the 674 enchytraeid, Cognettia sphagnetorum, adapt to increased drought stress? Soil Biology \& 675 Biochemistry, 40, 1765-1771.

676 Maraldo K, van der Linden L, Christensen B, Mikkelsen TN, Beier C, Krogh PH, Holmstrup 677 M (2010) The counteracting effects of elevated atmospheric $\mathrm{CO}_{2}$ concentrations and drought 678 episodes: studies of enchytraeid communities in dry heathland. Soil Biology and 679 Biochemistry, in press.

680 Marion GM, Hastings SJ, Oberbauer SF, Oechel WC (1989) Soil-plant element relationships 681 in a tundra ecosystem. Holarctic Ecology, 12, 296-303.

682 McGuire AD, Melillo JM, Joyce LA (1995) The role of nitrogen in the response of forest net 683 primary production to elevated atmospheric carbon-dioxide. Annual Review of Ecology and $684 \quad$ Systematics, 26, 473-503.

685 Mchale PJ, Mitchell MJ, Bowles FP (1998) Soil warming in a northern hardwood forest: trace 686 gas fluxes and leaf litter decomposition. Canadian Journal of Forest Research-Revue 687 Canadienne de Recherche Forestiere, 28, 1365-1372. 
688 Mikkelsen TN, Beier C, Jonasson S, et al. (2008) Experimental design of multifactor climate 689 change experiments with elevated $\mathrm{CO}_{2}$, warming and drought: the CLIMAITE project. $690 \quad$ Functional Ecology, 22, 185-195.

691 Morgan JA, Pataki DE, Körner C, et al. (2004) Water relations in grassland and desert 692 ecosystems exposed to elevated atmospheric $\mathrm{CO}_{2}$. Oecologia, 140, 11-25.

693 Nielsen PL, Andresen LC, Michelsen A, Schmidt IK, Kongstad J (2009) Seasonal variations 694 and effects of nutrient applications on $\mathrm{N}$ and $\mathrm{P}$ and microbial biomass under two temperate 695 heathland plants. Applied Soil Ecology, 42, 279-287.

696 Niklaus PA, Leadley PW, Schmid B, Körner C (2001) A long-term field study on biodiversity $697 \mathrm{x}$ elevated $\mathrm{CO}_{2}$ interactions in grassland. Ecological Monographs, 71, 341-356.

698 Nowak RS, Ellsworth DS, Smith SD (2004) Functional responses of plants to elevated 699 atmospheric $\mathrm{CO}_{2}$ - do photosynthetic and productivity data from FACE experiments support 700 early predictions? New Phytologist, 162, 253-280.

701 Osler GHR, Sommerkorn M (2007) Toward a complete soil C and N cycle: Incorporating the 702 soil fauna. Ecology, 88, 1611-1621.

703 Page FC (1988) A New Key to Freshwater and Soil Gymnamoebae. Freshwater Biological 704 Association, Cumbria, England.

705 Paterson E, Hodge A, Thornton B, Millard P, Killham K (1999) Carbon partitioning and 706 rhizosphere C-flow in Lolium perenne as affected by $\mathrm{CO}_{2}$ concentration, irradiance and 707 below-ground conditions. Global Change Biology, 5, 669-678. 
708 Peltola H, Kilpelainen A, Kellomaki S (2002) Diameter growth of Scots pine (Pinus

709 sylvestris) trees grown at elevated temperature and carbon dioxide concentration under boreal 710 conditions. Tree Physiology, 22, 963-972.

711 Pendall E, Mosier AR, Morgan JA (2004) Rhizodeposition stimulated by elevated $\mathrm{CO}_{2}$ in a 712 semiarid grassland. New Phytologist, 162, 447-458.

713 Penuelas J, Prieto P, Beier C, et al. (2007) Response of plant species richness and primary 714 productivity in shrublands along a north-south gradient in Europe to seven years of 715 experimental warming and drought: reductions in primary productivity in the heat and 716 drought year of 2003. Global Change Biology, 13, 2563-2581.

717 Persson T (1983) Influence of soil animals on nitrogen mineralisation in a northern Scots pine 718 forest. In: New Trends in Soil Biology (eds Lebrun P, André H, De Medts A, Grégoire-Wibo 719 C, Wauthy G), pp. 117-126. Dieu Brichart, Louvain-la-Neuve, Belgium.

720 Peterjohn WT, Melillo JM, Steudler PA, Newkirk KM, Bowles FP, Aber JD (1994)

721 Responses of trace gas fluxes and $\mathrm{N}$ availability to experimentally elevated soil temperatures. 722 Ecological Applications, 4, 617-625.

723 Petersen H, Luxton M (1982) A comparative-analysis of soil fauna populations and their role 724 in decomposition processes. Oikos, 39, 287-388.

725 Rastetter EB, Agren GI, Shaver GR (1997) Responses of N-limited ecosystems to increased $726 \mathrm{CO}_{2}$ : A balanced-nutrition, coupled-element-cycles model. Ecological Applications, 7, 444727460.

728 Reich PB, Hobbie SE, Lee T, et al. (2006) Nitrogen limitation constrains sustainability of 729 ecosystem response to $\mathrm{CO}_{2}$. Nature, $440,922-925$. 
730 Reich PB, Knops J, Tilman D, et al. (2001) Plant diversity enhances ecosystem responses to 731 elevated $\mathrm{CO}_{2}$ and nitrogen deposition. Nature, 410, 809-812.

732 Riis-Nielsen T, Schmidt IK (2010) Non-destructive plant biomass and cover estimates from 733 point intercept analysis - a case study of Calluna vulgaris and Deschampsia flexuosa.

734 Submitted May 2010 to Functional Ecology.

735 Rønn R, Ekelund F, Christensen S (1995) Optimizing soil extract and broth media for mpn736 enumeration of naked amoebas and heterotrophic flagellates in soil. Pedobiologia, 39, 10-19.

737 Rustad LE, Campbell JL, Marion GM, et al. (2001) A meta-analysis of the response of soil 738 respiration, net nitrogen mineralization, and aboveground plant growth to experimental 739 ecosystem warming. Oecologia, 126, 543-562.

740 SAS Institute (2003) SAS/STAT User's Guide. Statistical Analysis System Institute, Cary, 741 NC, USA.

742 Schimel JP, Bennett J (2004) Nitrogen mineralization: Challenges of a changing paradigm. 743 Ecology, 85, 591-602.

744 Schmidt IK, Beier C, Kongstad J, et al. (2007) Klimaændringer og processer og funktion i 745 terrestriske økosystemer. Flora og Fauna, 113, 121-132.

746 Schmidt IK, Tietema A, Williams D, Gundersen P, Beier C, Emmett BA, Estiarte M (2004)

747 Soil solution chemistry and element fluxes in three European heathlands and their responses 748 to warming and drought. Ecosystems, 7, 638-649.

749 Selsted MB, Ibrom A, Ambus P, et al. (2010) Soil respiration in a temperate heathland 750 responds strongly to elevated temperature, extended summer drought and elevated $\mathrm{CO}_{2}$.

751 Submitted July 2010 to Global Change Biology. 
752 Sohlenius B, Sandor A (1987) Vertical distribution of nematodes in arable soil under grass 753 (Festuca pratensis) and Barley (Hordeum vulgare). Biology and Fertility of Soils, 3, 19-25.

754 Sørensen P, Jensen ES (1991) Sequential diffusion of ammonium and nitrate from soil 755 extracts to a polytetrafluoroethylene trap for N-15 determination. Analytica Chimica Acta, $756 \quad 252,201-203$.

757 Sowerby A, Emmett BA, Tietema A, Beier C (2008) Contrasting effects of repeated summer 758 drought on soil carbon efflux in hydric and mesic heathland soils. Global Change Biology, 14, $759 \quad 2388-2404$.

760 Standen V (1973) Production and respiration of an enchytraeid population in blanket bog.

761 Journal of Animal Ecology, 42, 219-245.

762 Stout JD, Heal OW (1967) Protozoa. In: Soil Biology (eds Burges A, Raw F), pp. 149-195. 763 Academic Press, New York, USA.

764 Svensson M, Jansson PE, Gustafsson D, Kleja DB, Langvall O, Lindroth A (2008) Bayesian 765 calibration of a model describing carbon, water and heat fluxes for a Swedish boreal forest 766 stand. Ecological Modelling, 213, 331-344.

767 Tingey DT, McKane RB, Olszyk DM, Johnson MG, Rygiewicz PT, Lee EH (2003) Elevated $768 \mathrm{CO}_{2}$ and temperature alter nitrogen allocation in Douglas-fir. Global Change Biology, 9, $769 \quad 1038-1050$.

770 van der Linden L, Beier C, Mikkelsen TN, et al (2010) The effects of warming, drought and 771 elevated $\mathrm{CO}_{2}$ on the Carbon balance of a Danish heathland: the Climaite project carbon 772 synthesis. Expected submitted September 2010 to Global Change Biology. 
773 van Heerwaarden LM, Toet S, van Logtestijn RSP, Aerts R (2005) Internal nitrogen dynamics

774 in the graminoid Molinia caerulea under higher $\mathrm{N}$ supply and elevated $\mathrm{CO}_{2}$ concentrations.

775 Plant and Soil, 277, 255-264.

776 Vervaet H, Boeckx P, Boko AMC, Van Cleemput O, Hofman G (2004) The role of gross and

777 net $\mathrm{N}$ transformation processes and $\mathrm{NH}_{4}{ }^{+}$and $\mathrm{NO}_{3}{ }^{-}$immobilization in controlling the mineral

778 N pool of a temperate mixed deciduous forest soil. Plant and Soil, 264, 349-357.

779 Wolsing M, Prieme A (2004) Observation of high seasonal variation in community structure

780 of denitrifying bacteria in arable soil receiving artificial fertilizer and cattle manure by

781 determining T-RFLP of nir gene fragments. Fems Microbiology Ecology, 48, 261-271.

782 Zak DR, Pregitzer KS, Curtis PS, Teeri JA, Fogel R, Randlett DL (1993) Elevated

783 atmospheric $\mathrm{CO}_{2}$ and feedback between carbon and nitrogen cycles. Plant and Soil, 151, 105784117.

785 Zwart KB, Kuikman PJ, van Veen JA (1994) Rhizosphere Protozoa: their significance in 786 nutrient dynamics. In: Soil Protozoa (ed Darbyshire JF), CAB International, Wallingford, UK. 


\section{$788 \quad$ Figure captions}

789 Figure 1

790 Measured $\mathrm{N}$ pools in August 2007 (bold, $\mathrm{g} \mathrm{N} \mathrm{m}^{-2}$ ) and annual fluxes (italic, $\mathrm{g} \mathrm{N} \mathrm{m}^{-2} \mathrm{y}^{-1}$ ) in 791 ambient plots down to $10 \mathrm{~cm}$ soil depth (leaching below $60 \mathrm{~cm}$ depth) in 2007. Abbreviations:

792 Calluna vulgaris (Cal), Deschampsia flexuosa (Des), dissolved organic nitrogen (DON), 793 microbial biomass nitrogen (Mic-N), soil organic matter nitrogen (SOM-N), Gross 794 mineralization (Gross min). Data of litter N mass and litter N production was only available 795 for Deschampsia. Estimates of fauna biomass and mineralization includes enchytraeids, 796 microarthropods, nematodes, and protozoans. Dashed line indicates the major components 797 involved in $\mathrm{N}$ mineralization. The annual $\mathrm{N}$ balance was $+0.53 \mathrm{~g} \mathrm{~N} \mathrm{~m}^{-2} \mathrm{y}^{-1}$.

$799 \quad$ Figure 2

800 Observed above-ground changes in $\mathrm{N}$ pools, $\mathrm{C} / \mathrm{N}$ ratios, litter $\mathrm{N}$ production of Deschampsia 801 and percentage $\mathrm{N}$ in litter of Deschampsia caused by single treatments factors $(\mathrm{a}-\mathrm{c})$ and 802 when all treatments are combined (d). Calluna vulgaris (Cal), Deschampsia flexuosa (Des). 803 See Table 1 for statistical significance of observed changes.

$805 \quad$ Figure 3

806 Observed below-ground changes in $\mathrm{N}$ pools, $\mathrm{N}$ fluxes/processes and $\mathrm{N}$ concentrations caused 807 by single treatments factors $(\mathrm{a}-\mathrm{c})$ and when all treatments are combined $(\mathrm{d})$. Dissolved 808 organic nitrogen (DON), microbial biomass nitrogen (Mic-N), mineralization (min). See 
809 Table 1 for statistical significance of observed changes. 
811 Figure 4

812 Observed significant interactions $(\mathrm{P} \leq 0.05)$ from the PROC MIXED analysis of 47

813 individually tested variables (see Table 1) followed by analysis of Differences of Least

814 Squares Means (DLSM) were categorized as antagonistic, i.e. combination leads to reduction

815 of effects, or as synergistic, i.e. combination leads to amplification of single effects or

816 significant effect is only observed in combination. Number of observed simple additive

817 effects is also shown, i.e. cases where two significant individual effects were observed

818 without significant interaction. Note that the sum of antagonistic and synergistic effects are 15

819 because one three-way interaction (potential nitrification - see Table 1) was caused by both 820 antagonistic and synergistic effects. 
Table 1. Pools and fluxes of $\mathrm{N}\left(\mathrm{g} \mathrm{N} \mathrm{m}^{-2}\right), \mathrm{C} / \mathrm{N}$ ratios and $\mathrm{N}$ concentrations $\left(\mathrm{mg} \mathrm{L}^{-1}\right)$ in 2007. Data are means with SE for ambient (A) and means with SE normalized to the mean of the ambient treatment (all other treatments than A). ${ }^{1}$ Significant $\mathrm{P}$ values $(P$ single treatment effects as indicated by evaluation of main effects plus interaction(s) by analysis of DLSM (see text for further details). Direction of effects is indicated with arrows. n.s. = not significant.

\begin{tabular}{|c|c|c|c|c|c|c|c|c|c|c|c|c|c|c|c|c|c|c|}
\hline & \multirow{3}{*}{ A } & \multirow[b]{2}{*}{$\mathrm{CO}_{2}$} & \multirow[b]{2}{*}{ D } & \multirow[b]{2}{*}{$\mathrm{T}$} & \multirow[b]{2}{*}{$\mathrm{DCO}_{2}$} & \multirow[b]{2}{*}{$\mathrm{TCO}_{2}$} & \multirow[b]{2}{*}{ TD } & \multirow{3}{*}{$\mathrm{TDCO}_{2}$} & \multicolumn{3}{|c|}{ main treatment effects) } & \multicolumn{4}{|c|}{ Interactions" } & \multicolumn{3}{|c|}{ single treatment effects's) } \\
\hline & & & & & & & & & $\mathrm{CO}_{2}$ & D & & $\mathrm{D}^{*} \mathrm{CO}_{2}$ & $\mathrm{~T}^{*} \mathrm{CO}_{2}$ & $T^{*} D$ & $\mathrm{~T}^{*} \mathrm{D}^{*} \mathrm{CO}_{2}$ & & & \\
\hline & & $101+0.09$ & $0.88+0.09$ & $0.96+0.21 .>20-10$ & $0.80+0.19$ & $0.97+0.20$ & $0.84+0.13$ & & & & & & & & & & & \\
\hline C/N ratio of Calluna leaves & $\begin{array}{l}0.14 \pm 25 \% \\
26.4 \pm 7 \%\end{array}$ & $1.17 \pm 0.05$ & $\begin{array}{l}.080 \pm 0.09 \\
1.07 \pm 0.04\end{array}$ & $\begin{array}{l}.090 \pm 0.21 \\
1.03 \pm 0.09\end{array}$ & $\begin{array}{l}0.114 \pm 0.08 \\
1.19\end{array}$ & $1.15 \pm 0.12$ & $0.97 \pm 0.03$ & $\begin{array}{l}0.15 \pm 0.09 \\
1.15\end{array}$ & $0.02 \uparrow$ & & & & & & & $0.02 \uparrow$ & & \\
\hline $\mathrm{C} / \mathrm{N}$ ratio of Calluna flowers & $29.5 \pm 4 \%$ & $1.17 \pm 0.09$ & $1.09 \pm 0.05$ & $1.04 \pm 0.07$ & $1.16 \pm 0.06$ & $1.15 \pm 0.05$ & $1.09 \pm 0.04$ & $1.21 \pm 0.04$ & $0.04 \uparrow$ & & & & & & & $0.04 \uparrow$ & & \\
\hline $\mathrm{C} / \mathrm{N}$ ratio of Calluna green tissue & $28.1 \pm 5 \%$ & $0.94 \pm 0.08$ & $0.94 \pm 0.08$ & $0.90 \pm 0.07$ & $1.09 \pm 0.04$ & $0.88 \pm 0.06$ & $0.97 \pm 0.05$ & $0.98 \pm 0.06$ & & & & & & & & & & \\
\hline $\mathrm{C} / \mathrm{N}$ ratio of Calluna wood & $56.7 \pm 9 \%$ & $0.97 \pm 0.08$ & $1.00 \pm 0.10$ & $0.94 \pm 0.07$ & $1.03 \pm 0.06$ & $0.95 \pm 0.08$ & $1.06 \pm 0.08$ & $1.16 \pm 0.02$ & & & & & & & & & & \\
\hline Deschampsia & $2.99 \pm 20 \%$ & $0.89 \pm 0.07$ & $1.20 \pm 0.27$ & $0.97 \pm 0.27$ & $0.94 \pm 0.21$ & $1.05 \pm 0.18$ & $0.73 \pm 0.17$ & $0.78 \pm 0.06$ & & & & & & & & & & \\
\hline $\mathrm{C} / \mathrm{N}$ ratio of Deschampsia green leaves & $22.2 \pm 6 \%$ & $1.16 \pm 0.02$ & $1.16 \pm 0.12$ & $1.05 \pm 0.07$ & $1.39 \pm 0.07$ & $1.27 \pm 0.11$ & $1.18 \pm 0.05$ & $1.40 \pm 0.07$ & $0.01 \uparrow$ & $0.002 \uparrow$ & & + & & & & $0.01 \uparrow$ & $0.002 \uparrow$ & \\
\hline $\mathrm{C} / \mathrm{N}$ ratio of Deschampsia whole plant & $23.3 \pm 8 \%$ & $1.08 \pm 0.06$ & $0.92 \pm 0.09$ & $1.07 \pm 0.14$ & $1.25 \pm 0.15$ & $0.90 \pm 0.04$ & $1.07 \pm 0.10$ & $1.12 \pm 0.06$ & & & & & & & & & & \\
\hline $\begin{array}{l}\text { Mosses } \\
\end{array}$ & $0.930 \pm 53 \%$ & $3.20 \pm 1.10$ & $3.95 \pm 1.65$ & $2.57 \pm 0.89$ & $1.54 \pm 0.73$ & $1.95 \pm 0.67$ & $2.48 \pm 1.20$ & $1.77 \pm 1.22$ & & & & & & & & & & \\
\hline $\mathrm{C} / \mathrm{N}$ ratio of mosses & $19.4 \pm 5 \%$ & $1.44 \pm 0.15$ & $1.31 \pm 0.15$ & $1.24 \pm 0.09$ & $1.12 \pm 0.18$ & $0.97 \pm 0.13$ & $1.16 \pm 0.15$ & $1.02 \pm 0.11$ & & & & & & & $0.003 \S$ & $0.05 \uparrow$ & $0.05 \uparrow$ & \\
\hline Litter $\mathbf{N}$ & & & & & & & & & & & & & & & & & & \\
\hline Deschampsia & $0.095 \pm 52 \%$ & $0.56 \pm 0.19$ & $0.19 \pm 0.04$ & $0.15 \pm 0.04$ & $0.64 \pm 0.32$ & $0.46 \pm 0.17$ & $0.21 \pm 0.15$ & $0.58 \pm 0.17$ & & & & & & & & & & \\
\hline Deschampsia litter $\mathrm{N}$ conc. & $0.936 \pm 12 \%$ & $0.76 \pm 0.11$ & $1.05 \pm 0.08$ & $1.07 \pm 0.12$ & $0.75 \pm 0.12$ & $0.88 \pm 0.09$ & $1.15 \pm 0.15$ & $1.06 \pm 0.08$ & $0.05 \downarrow$ & & $0.03 \uparrow$ & & + & & & $0.05 \downarrow$ & & $0.03 \uparrow$ \\
\hline Deschampsia litter $\mathrm{N}$ production & $1.42 \pm 28 \%$ & $0.92 \pm 0.22$ & $0.69 \pm 0.28$ & $1.05 \pm 0.51$ & $0.64 \pm 0.18$ & $1.17 \pm 0.20$ & $0.73 \pm 0.25$ & $0.77 \pm 0.14$ & & $0.01 \downarrow$ & & & & & & & $0.01 \downarrow$ & \\
\hline Plant root biomass $\mathrm{N}(0-10 \mathrm{~cm})$ & & & & & & & & & & & & & & & & & & \\
\hline Calluna & $7.56 \pm 35 \%$ & $0.98 \pm 0.24$ & $1.73 \pm 0.34$ & $1.47 \pm 0.35$ & $1.90 \pm 0.42$ & $0.86 \pm 0.29$ & $1.71 \pm 0.31$ & $1.23 \pm 0.38$ & & $0.04 \uparrow$ & & & & & & & $0.04 \uparrow$ & \\
\hline Deschampsia & $10.3 \pm 29 \%$ & $0.67 \pm 0.22$ & $0.60 \pm 0.14$ & $0.56 \pm 0.10$ & $0.67 \pm 0.18$ & $0.65 \pm 0.22$ & $0.45 \pm 0.10$ & $0.59 \pm 0.15$ & & & & & & & & & & \\
\hline Soil microbial biomass $\mathrm{N}$ and soil fauna $\mathrm{N}(0-$ & & & & & & & & & & & & & & & & & & \\
\hline Microbes & $3.55 \pm 16 \%$ & $1.46 \pm 0.39$ & $1.32 \pm 0.20$ & $1.46 \pm 0.20$ & $1.27 \pm 0.36$ & $1.16 \pm 0.28$ & $1.03 \pm 0.15$ & $1.02 \pm 0.22$ & & & & & & & & & & \\
\hline Enchytraeids & $0.197 \pm 10 \%$ & $1.62 \pm 0.50$ & $0.71 \pm 0.15$ & $1.19 \pm 0.38$ & $1.00 \pm 0.26$ & $1.02 \pm 0.15$ & $0.53 \pm 0.10$ & $1.14 \pm 0.39$ & & $0.03 \downarrow$ & & & & & & & $0.03 \downarrow$ & \\
\hline Microarthropods & $0.064 \pm 28 \%$ & $2.18 \pm 0.82$ & $1.53 \pm 0.38$ & $1.84 \pm 0.53$ & $1.36 \pm 0.49$ & $1.61 \pm 0.33$ & $1.92 \pm 0.27$ & $1.82 \pm 0.47$ & & & & & & & & & & \\
\hline Nematodes & $0.007 \pm 12 \%$ & $1.46 \pm 0.32$ & $0.84 \pm 0.18$ & $1.21 \pm 0.27$ & $1.31 \pm 0.48$ & $0.95 \pm 0.11$ & $1.05 \pm 0.19$ & $0.97 \pm 0.16$ & & & & & & & & & & \\
\hline Protozoans & $0.011 \pm 44 \%$ & $0.55 \pm 0.13$ & $0.82 \pm 0.19$ & $1.47 \pm 0.47$ & $0.36 \pm 0.11$ & $1.29 \pm 0.82$ & $0.61 \pm 0.15$ & $0.37 \pm 0.09$ & & $0.04 \downarrow$ & & & & & & & $0.04 \downarrow$ & \\
\hline Annual enchytraeid mineralization & $0.592 \pm 10 \%$ & $1.62 \pm 0.50$ & $0.71 \pm 0.15$ & $1.19 \pm 0.38$ & $1.00 \pm 0.26$ & $1.02 \pm 0.15$ & $0.53 \pm 0.10$ & $1.14 \pm 0.39$ & & $0.03 \downarrow$ & & & & & & & $0.03 \downarrow$ & \\
\hline Annual microarthropod mineralization & $0.191 \pm 28 \%$ & $2.18 \pm 0.82$ & $1.53 \pm 0.38$ & $1.84 \pm 0.53$ & $1.36 \pm 0.49$ & $1.61 \pm 0.33$ & $1.92 \pm 0.27$ & $1.82 \pm 0.47$ & & & & & & & & & & \\
\hline $\begin{array}{l}\text { Annual nematode mineralization } \\
\text { Annual protozoan mineralization }\end{array}$ & $\begin{array}{l}2.63 \pm 12 \% \\
1.58+44 \%\end{array}$ & $\begin{array}{l}1.46 \pm 0.32 \\
0.55 \pm 0.13\end{array}$ & $\begin{array}{l}0.84 \pm 0.18 \\
0.82+0.19\end{array}$ & $\begin{array}{l}1.21 \pm 0.27 \\
1.47+0.47\end{array}$ & $\begin{array}{l}1.31 \pm 0.48 \\
0.36+0.11\end{array}$ & $0.95 \pm 0.11$ & $\begin{array}{l}1.05 \pm 0.19 \\
0.61+0.15\end{array}$ & $\begin{array}{l}0.97 \pm 0.16 \\
0.37+0.09\end{array}$ & & $0.04 \downarrow$ & & & & & & & $0.04 \downarrow$ & \\
\hline & & & & & & 2 & & & & & & & & & & & & \\
\hline $\begin{array}{l}\text { Soli organic and inorganic } \mathrm{N} \text { pools and co } \\
\text { SOM-N }(0-10 \mathrm{~cm})\end{array}$ & $180.2 \pm 5 \%$ & $1.19 \pm 0.14$ & $1.08 \pm 0.11$ & $0.81 \pm 0.04$ & $1.30 \pm 0.36$ & $0.85 \pm 0.07$ & $0.86 \pm 0.09$ & $1.11 \pm 0.16$ & & & & & & & & & & \\
\hline Extractable soil $\mathrm{NO}_{3}-\mathrm{N}(0-10 \mathrm{~cm})$ & $0.004 \pm 15 \%$ & $1.37 \pm 0.26$ & $1.15 \pm 0.19$ & $1.06 \pm 0.16$ & $1.42 \pm 0.47$ & $1.02 \pm 0.08$ & $0.85 \pm 0.09$ & $1.13 \pm 0.27$ & & & & & & & & & & \\
\hline Extractable soil $\mathrm{NH}_{4}{ }^{+} \mathrm{N}(0-10 \mathrm{~cm})$ & $0.330 \pm 52 \%$ & $0.76 \pm 0.47$ & $0.58 \pm 0.50$ & $0.87 \pm 0.33$ & $0.72 \pm 0.37$ & $3.29 \pm 0.99$ & $0.19 \pm 0.06$ & $0.19 \pm 0.05$ & & $0.02 \downarrow$ & & & & & & & $0.02 \downarrow$ & \\
\hline Extractable soil DON $(0-10 \mathrm{~cm})$ & $1.59 \pm 16 \%$ & $1.07 \pm 0.19$ & $0.90 \pm 0.10$ & $1.25 \pm 0.17$ & $1.20 \pm 0.23$ & $0.71 \pm 0.15$ & $0.92 \pm 0.12$ & $0.85 \pm 0.17$ & & & & & $0.04 \ddagger$ & & & & & \\
\hline Mean annual leachate $\mathrm{NO}_{3}-\mathrm{N}$ conc. $(-5 \mathrm{~cm})$ & $7.39 \pm 22 \%$ & $0.24 \pm 0.01$ & $0.56 \pm 0.07$ & $1.01 \pm 0.10$ & $0.68 \pm 0.08$ & $0.93 \pm 0.23$ & $0.80 \pm 0.06$ & $0.71 \pm 0.11$ & & & $0.01 \uparrow$ & 0.0025 & & & 0.035 & $0.05 \downarrow$ & $0.05 \downarrow$ & n.s. \\
\hline Mean annual leachate $\mathrm{NH}_{4}^{+}-\mathrm{N}$ conc. $(-5 \mathrm{~cm})$ & $6.87 \pm 18 \%$ & $1.10 \pm 0.09$ & $1.76 \pm 0.48$ & $1.21 \pm 0.13$ & $1.05 \pm 0.19$ & $2.13 \pm 0.51$ & $1.35 \pm 0.16$ & $1.06 \pm 0.09$ & & & & $0.004 \S$ & & & & & $0.05 \uparrow$ & \\
\hline Mean annual leachate DON conc. $(-5 \mathrm{~cm})$ & $21.4 \pm 16 \%$ & $0.70 \pm 0.05$ & $1.25 \pm 0.25$ & $1.09 \pm 0.08$ & $0.89 \pm 0.11$ & $1.43 \pm 0.28$ & $1.06 \pm 0.05$ & $1.07 \pm 0.09$ & & $0.01 \uparrow$ & & & $0.02 \S$ & & & $0.05 \downarrow$ & $0.01 \uparrow$ & \\
\hline Mean annual leachate total $N$ conc. $(-5 \mathrm{~cm})$ & $7.23 \pm 10 \%$ & $0.80 \pm 0.04$ & $1.45 \pm 0.25$ & $1.04 \pm 0.05$ & $0.96 \pm 0.11$ & $1.28 \pm 0.13$ & $1.03 \pm 0.04$ & $1.42 \pm 0.15$ & & & & & $0.05 \S$ & & & $0.05 \downarrow$ & & \\
\hline Mean annual leachate $\mathrm{NO}_{3}-\mathrm{N}$ conc. $(-60 \mathrm{~cm})$ & $2.04 \pm 68 \%$ & $0.27 \pm 0.12$ & $0.72 \pm 0.30$ & $0.57 \pm 0.39$ & $0.45 \pm 0.23$ & $0.58 \pm 0.29$ & $1.22 \pm 0.51$ & $0.30 \pm 0.10$ & & & & & & & & & & \\
\hline Mean annual leachate $\mathrm{NH}_{4}^{+}{ }^{-} \mathrm{N}$ conc. $(-60 \mathrm{~cm})$ & $0.140 \pm 20 \%$ & $0.66 \pm 0.05$ & $1.46 \pm 0.33$ & $1.66 \pm 0.67$ & $1.81 \pm 0.88$ & $2.63 \pm 1.56$ & $0.81 \pm 0.15$ & $1.05 \pm 0.39$ & & & & & & & & & & \\
\hline Mean annual leachate DON conc. $(-60 \mathrm{~cm})$ & $2.60 \pm 59 \%$ & $0.37 \pm 0.10$ & $0.80 \pm 0.25$ & $0.63 \pm 0.36$ & $0.60 \pm 0.24$ & $0.74 \pm 0.23$ & $1.13 \pm 0.45$ & $0.42 \pm 0.09$ & & & & & & & & & & \\
\hline Mean annual leachate total $N$ conc. $(-60 \mathrm{~cm})$ & $0.444 \pm 30 \%$ & $0.73 \pm 0.17$ & $0.94 \pm 0.19$ & $0.78 \pm 0.32$ & $0.95 \pm 0.33$ & $0.93 \pm 0.20$ & $0.97 \pm 0.41$ & $0.69 \pm 0.11$ & & & & & & & & & & \\
\hline seous fluxes & & & & & & & & & & & & & & & & & & \\
\hline Annual $\mathrm{N}_{2} \mathrm{O}$ emission & $0.031 \pm 18 \%$ & $0.78 \pm 0.35$ & $0.89 \pm 0.25$ & $0.95 \pm 0.21$ & $0.52 \pm 0.16$ & $1.66 \pm 0.23$ & $1.07 \pm 0.18$ & $1.06 \pm 0.21$ & & $0.05 \downarrow$ & $0.05 \uparrow$ & $0.04 \ddagger$ & & + & & & n.s. & $0.05 \uparrow$ \\
\hline Mineralisation, immobilisation and nitrificati & & & & & & & & & & & & & & & & & & \\
\hline Annual $\mathrm{NH}_{4}{ }_{4}$ Consumption $(0-5 \mathrm{~cm})$ & $3.21 \pm 19 \%$ & $1.16 \pm 0.17$ & $1.18 \pm 0.16$ & $2.50 \pm 0.54$ & $1.76 \pm 0.19$ & $2.06 \pm 0.39$ & $1.87 \pm 0.15$ & $0.90 \pm 0.06$ & & & $0.04 \uparrow$ & & $0.04 \S$ & $0.01 \S$ & & & & $0.04 \uparrow$ \\
\hline Annual gross mineralisation $(0-5 \mathrm{~cm})$ & $4.27 \pm 9 \%$ & $0.97 \pm 0.09$ & $0.93 \pm 0.11$ & $1.45 \pm 0.22$ & $1.41 \pm 0.20$ & $1.45 \pm 0.15$ & $1.25 \pm 0.08$ & $0.80 \pm 0.03$ & & $0.03 \downarrow$ & & & $0.02 \S$ & & $0.03 \ddagger$ & & $0.03 \downarrow$ & $0.05 \uparrow$ \\
\hline Annual $\mathrm{NH}_{4}{ }^{+}$consumption $(5-10 \mathrm{~cm})$ & $5.6 \pm 70 \%$ & $0.79 \pm 0.13$ & $1.89 \pm 0.73$ & $1.01 \pm 0.32$ & $0.45 \pm 0.29$ & $0.16 \pm 0.04$ & $0.17 \pm 0.04$ & $0.56 \pm 0.11$ & & & & & & & 0.035 & & $0.05 \uparrow$ & \\
\hline Annual gross mineralisation $(5-10 \mathrm{~cm})$ & $2.40 \pm 24$ & $2.16 \pm 0.61$ & $2.75 \pm 1.70$ & $1.54 \pm \mathrm{C}$ & $1.74 \pm 0$ & 0.93 & $0.87 \pm$ & $1.40 \pm$ & & & & & & & & & & \\
\hline Potential nitrification $(0-10 \mathrm{~cm})$ & $0.159 \pm 44 \%$ & $0.22 \pm 0.20$ & $1.01 \pm 0.53$ & $1.69 \pm 0.61$ & $1.23 \pm 0.80$ & $1.53 \pm 0.63$ & $3.15 \pm 1.03$ & $1.16 \pm 0.54$ & & & $0.004 \uparrow$ & & & & $0.035 \ddagger$ & & & $0.004 \uparrow$ \\
\hline Potential denitrification $(0-10 \mathrm{~cm})$ & $33.9 \pm 29 \%$ & $1.03 \pm 0.26$ & $1.24 \pm 0.35$ & $1.61 \pm 0.58$ & $0.99 \pm 0.38$ & $1.08 \pm 0.36$ & $1.95 \pm 0.40$ & $1.49 \pm 0.36$ & & & $0.02 \uparrow$ & & & & & & & $0.02 \uparrow$ \\
\hline N Leaching & & & & & & & & & & & & & & & & & & \\
\hline Annual $\mathrm{NO}_{3}-\mathrm{N}$ leaching $(-60 \mathrm{~cm})$ & $0.619 \pm 62 \%$ & $0.31 \pm 0.16$ & $0.73 \pm 0.32$ & $0.32 \pm 0.18$ & $0.39 \pm 0.20$ & $0.65 \pm 0.28$ & $1.00 \pm 0.38$ & $0.28 \pm 0.09$ & & & & & & & & & & \\
\hline Annual $\mathrm{NH}_{4}^{+}-\mathrm{N}$ leaching $(-60 \mathrm{~cm})$ & $0.045 \pm 27 \%$ & $0.68 \pm 0.06$ & $1.48 \pm 0.37$ & $1.98 \pm 0.46$ & $2.01 \pm 1.14$ & $2.76 \pm 1.40$ & $0.74 \pm 0.12$ & $1.24 \pm 0.49$ & & & & & & & & & & \\
\hline Annual DON leaching $(-60 \mathrm{~cm})$ & $0.144 \pm 24 \%$ & $0.94 \pm 0.24$ & $1.02 \pm 0.23$ & $0.86 \pm 0.29$ & $1.35 \pm 0.72$ & $1.46 \pm 0.39$ & $0.90 \pm 0.38$ & $0.64 \pm 0.11$ & & & & & & & & & & \\
\hline Annual total $\mathrm{N}$ leaching $(-60 \mathrm{~cm})$ & $0.804 \pm 53 \%$ & $0.44 \pm 0.16$ & $0.83 \pm 0.27$ & $0.48 \pm 0.20$ & $0.64 \pm 0.28$ & $0.90 \pm 0.27$ & $0.95 \pm 0.35$ & $0.39 \pm 0.08$ & & & & & & & & & & \\
\hline
\end{tabular}


Figure 1
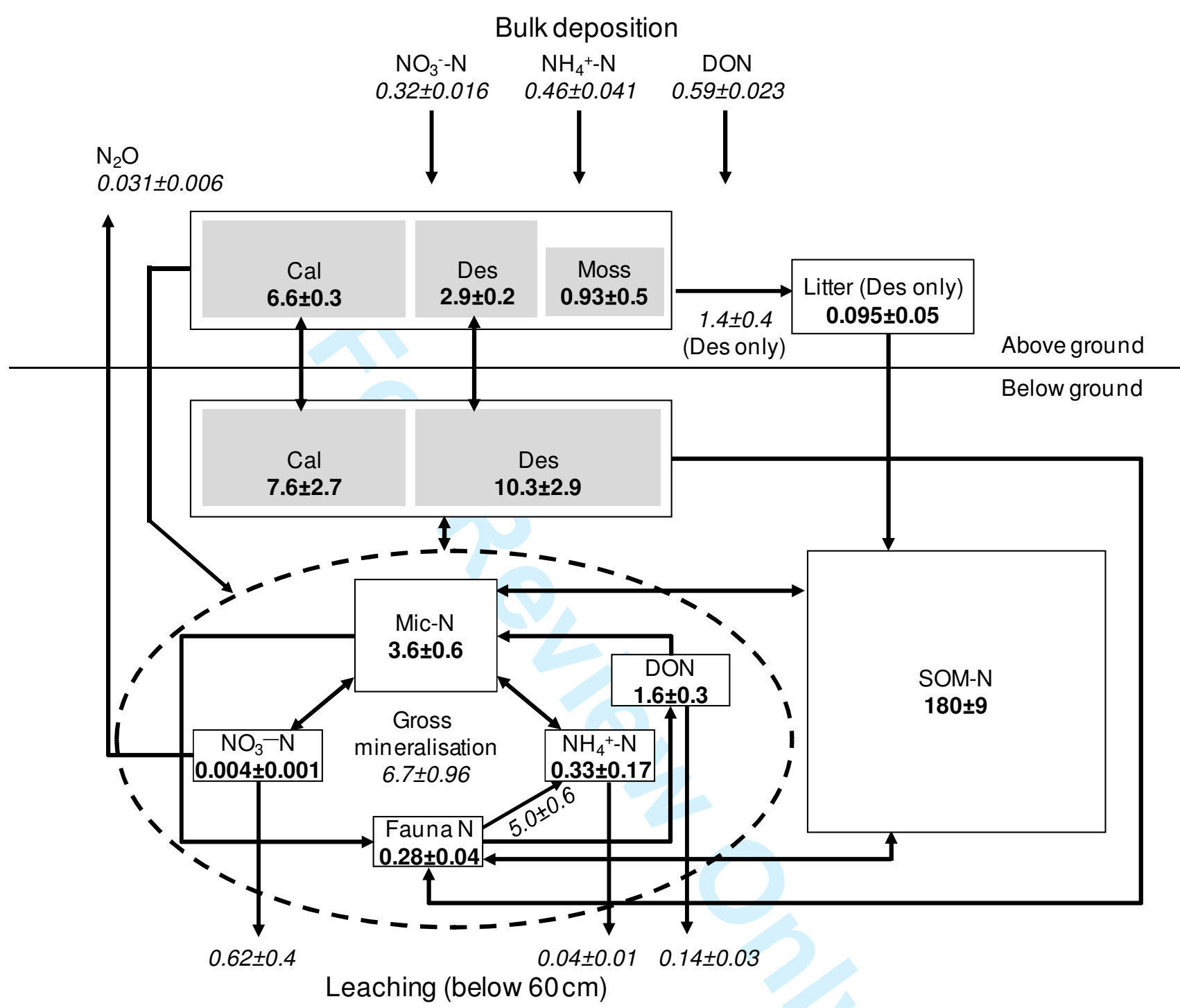
Figure 2

(a) $\mathrm{CO}_{2}$

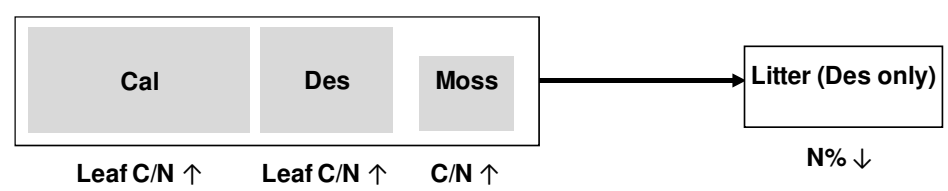

(b) Drought

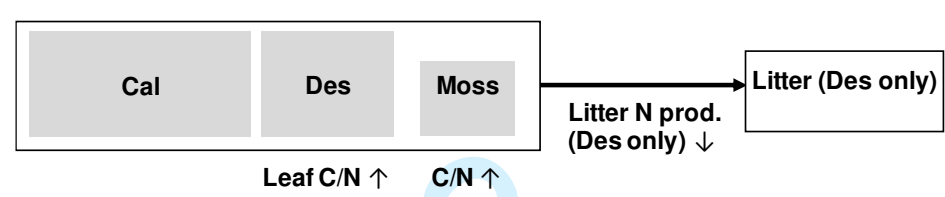

(c) Warming

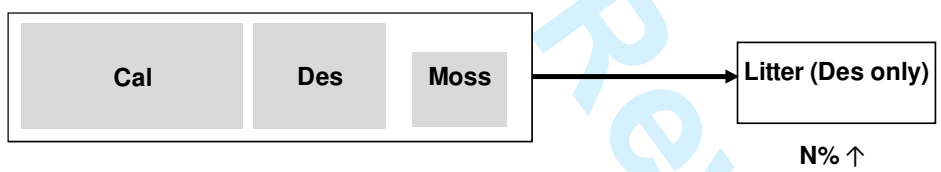

(d) $\mathrm{CO}_{2}$, drought and warming

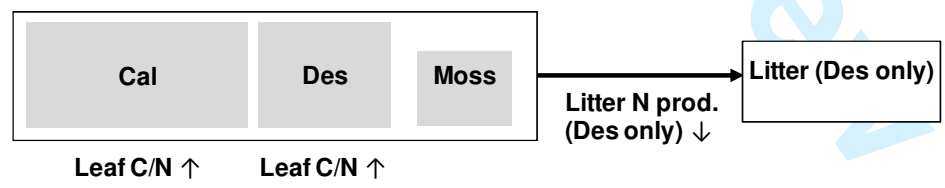


Figure 3

(a) $\mathrm{CO}_{2}$

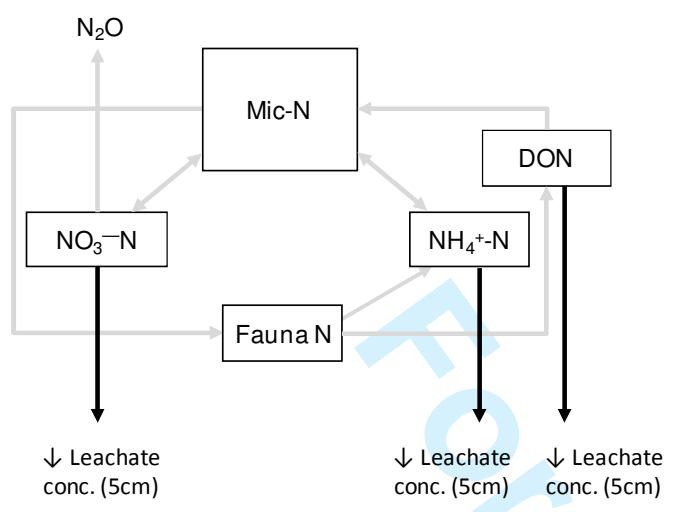

(c) Warming

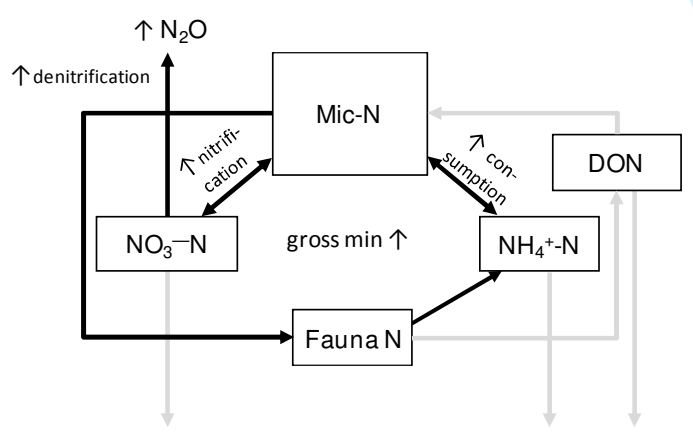

(b) Drought

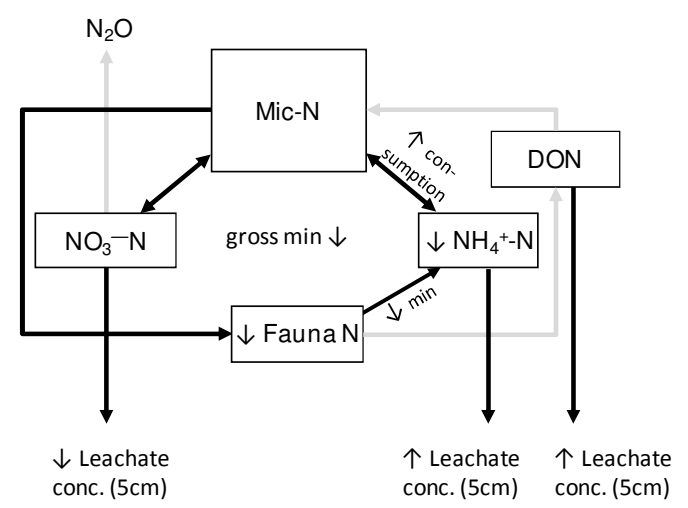

(d) $\mathrm{CO}_{2}$, drought and warming

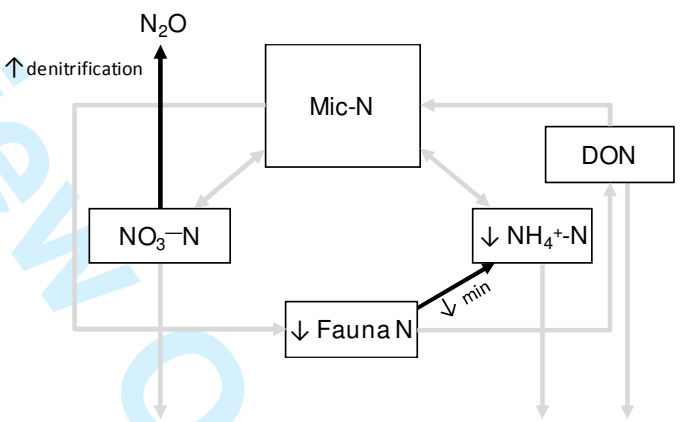


Figure 4

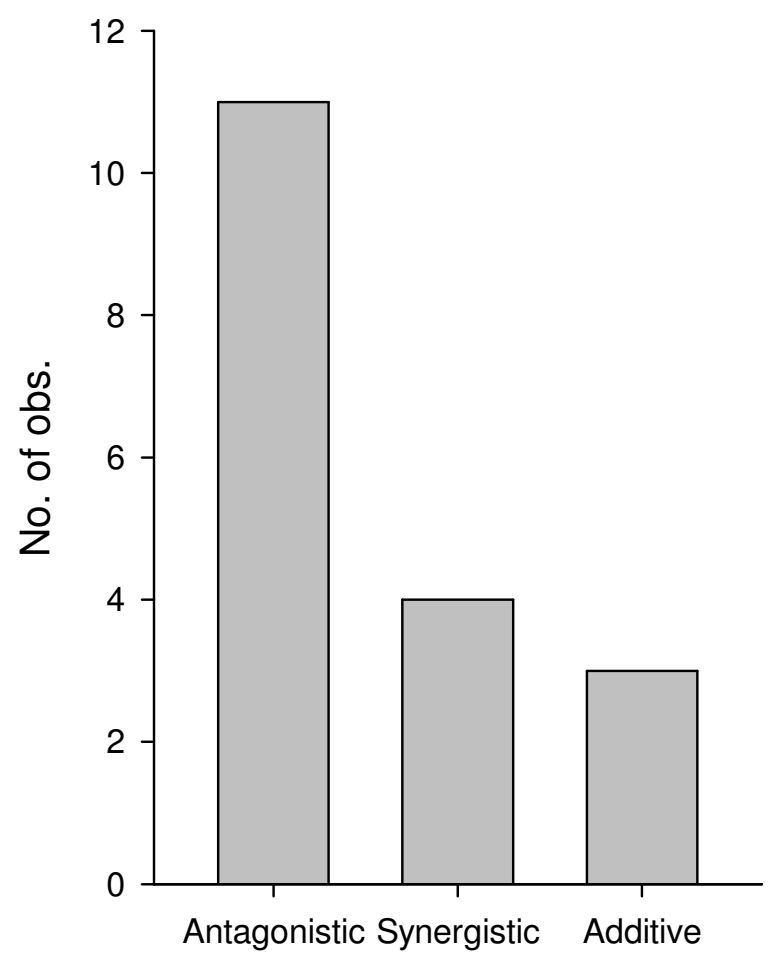

